\title{
Adaptive interference suppression strategies for a satellite on-board filter bank under tone-type interfering environments
}

DOI:

10.1587/transcom.E94.B.2978

Link to publication record in Manchester Research Explorer

Citation for published version (APA):

Kirchmaier, T., Ahn, J., \& Kim, K. (2011). Adaptive interference suppression strategies for a satellite on-board filter bank under tone-type interfering environments. In IEICE Transactions on Communications/IEICE Trans Commun (Vol. E94-B, pp. 2978-2982) https://doi.org/10.1587/transcom.E94.B.2978

\section{Published in:}

IEICE Transactions on Communications|IEICE Trans Commun

\section{Citing this paper}

Please note that where the full-text provided on Manchester Research Explorer is the Author Accepted Manuscript or Proof version this may differ from the final Published version. If citing, it is advised that you check and use the publisher's definitive version.

\section{General rights}

Copyright and moral rights for the publications made accessible in the Research Explorer are retained by the authors and/or other copyright owners and it is a condition of accessing publications that users recognise and abide by the legal requirements associated with these rights.

\section{Takedown policy}

If you believe that this document breaches copyright please refer to the University of Manchester's Takedown Procedures [http://man.ac.uk/04Y6Bo] or contact uml.scholarlycommunications@manchester.ac.uk providing relevant details, so we can investigate your claim.

\section{OPEN ACCESS}




\title{
Boards of Banks ${ }^{1}$
}

\author{
Daniel Ferreira \\ London School of Economics, CEPR and ECGI
}

Tom Kirchmaier

Manchester Business School and

Financial Markets Group, London School of Economics

\author{
Daniel Metzger \\ Stockholm School of Economics and \\ Financial Markets Group, London School of Economics
}

First Draft: March 31, 2010

This Version: September 15, 2011

\begin{abstract}
We show that country characteristics explain most of the cross-sectional variation in bank board independence. In contrast, country characteristics have little explanatory power for the fraction of outside bank directors with experience in the banking industry. Exploiting the time-series dimension of the sample, we show that changes in bank characteristics are not robustly associated with changes in board independence, while changes in board experience are positively related to changes in bank size and negatively related to changes in performance. The evidence suggests that country-specific laws and regulations affect the composition of boards of banks mainly through requirements for director independence.
\end{abstract}

\footnotetext{
${ }^{1}$ Ferreira: D.Ferreira@1se.ac.uk; Kirchmaier: T.Kirchmaier@1se.ac.uk; Metzger: Daniel.Metzger@hhs.se. We thank Renée Adams, Ulf Axelson, Lucas Barros, Martin Cihak, Aleksandra Gregoric, Maria Gutierrez, Marc Steffen Rapp, David Kershaw, and seminar audiences at the London School of Economics, Manchester Business School, Oxford, Lancaster, Mannheim, Vienna Graduate School of Finance, ESSEC Business School, U. ParisDauphine, U. of Porto, ISCTE, the UK's Financial Services Authority (FSA), Bank of Italy, ECGI/CEPR conference on Governance and Regulation of Financial Institutions (Madrid), EURAM 2010, the CEPRGerzensee Summer Symposium, the 2010 Asian Finance Association conference, the 2009 Workshop on Corporate Governance at the Copenhagen Business School, and the conference on Rebuilding Confidence in Financial Markets at the LSE for comments. Special thanks also to Michael von Brentano, Martin Jacomb and Geoffrey Owen for providing the practitioner's view. We thank the generous support of the AXA Research Fund through FMG's risk management and regulation of financial institutions research project, and seed funding from MBS. Along with many others, Min Park, Aljona Rebakovski, and Niklas Röhling provided excellent research assistance.
} 
The recent global financial crisis has brought bank governance into the spotlight. Regulatory proposals in the aftermath of the crisis have singled out boards of banks as one of their main targets (Kirkpatrick (2009); Walker (2009); and European Commission (2010)). These calls for regulation are mostly based on circumstantial and anecdotal evidence, as we currently know little about the characteristics of boards of banks and their relation to firm and country characteristics. We also do not know how existing regulations shape the structure of bank boards.

In this paper we study the characteristics of boards of banks around the world. We have two goals. The first one is to provide the most comprehensive and detailed analysis to date of the determinants of bank board characteristics. The second goal is to assess the extent to which regulation affects bank board composition.

Our focus is on two characteristics of outside (nonexecutive) bank directors: independence (from management) and experience (in the banking industry). We take no stand on whether director independence and director experience are good or bad. That is, we do not equate either independence or experience with good governance. We are interested in these variables because of their policy relevance. For example, some recent reform-minded reports identify insufficient director independence from managers and directors' lack of banking expertise as two of the main causes of the governance failures that contributed to the 2007-09 banking crisis (Kirkpatrick (2009); Walker (2009); and European Commission (2010)).

Our evidence suggests that board independence and board experience are determined in significantly different ways. In the cross-section, the variation in bank board independence is mostly explained by country characteristics, suggesting that regulation and other institutional features are more important than bank-specific and idiosyncratic factors. In contrast, neither country nor bank characteristics explain much of the cross-sectional variation in board experience. In the time-series, we find that year effects are important, and that 
independence and experience evolve in opposite directions, especially in the US. Once we factor out aggregate trends and time-invariant bank characteristics, we find that changes in bank characteristics have no statistically robust impact on board independence, which is consistent with the view that bank-specific characteristics have little influence on board independence. In contrast, bank characteristics matter substantially for board experience. We find some robust evidence that changes in board experience are positively related to changes in bank size and negatively related to changes in bank performance.

A possible explanation for our findings is as follows. Regulation (both direct and indirect) and business practices (often reflected in governance codes) vary substantially across countries. This variation may explain the importance of country effects for board composition. But regulation is likely to affect board independence more than board experience. Director independence has been on the top of the agenda of regulators and governance activists for some time. For example, director independence featured prominently in the cluster of governance reforms associated with the Sarbanes-Oxley Act of 2002. In contrast, director expertise has only recently been considered an important issue, mainly in the context of the role of banks in the financial crisis (e.g. Walker (2009)). Thus, if banks have little freedom in choosing their board independence levels, country effects should be the main determinant of board independence. By the same logic, if regulation plays a minor role in determining bank directors' expertise, country effects should be irrelevant for board experience. Furthermore, if banks actively change their boards in response to changes in the business environment, changes in board experience could occur in tandem with changes in some other bank characteristics.

Our results raise some important questions. For example, would banks benefit from being less regulated, allowing them to tailor board independence to their specific needs? Or is regulation actually preventing them from choosing inferior governance structures? Although 
answering these questions is beyond the scope of this paper, the evidence in this paper underscores their importance.

Our study exploits a unique dataset of director characteristics that we construct by collecting detailed biographic data for a sample of 12,010 directors working for 740 publiclylisted banks. The sample spans 9 years (2000-2008) and includes banks from 41 countries. We collect data on four board/director characteristics: director independence, previous banking experience, board size, and director busyness. We match our director data with data on bank and country characteristics.

A reliable and meaningful measure of board independence is difficult to obtain. Some previous studies consider the proportion of outside directors on the board as a proxy for independence. This is a crude approximation, but it might be the only alternative when working with samples that span periods for which better data are not available (see e.g., Linck, Netter, and Yang (2009); and Ferreira, Ferreira, and Raposo (2011)). Some papers use finer proxies for independence (e.g., Adams (2009); and Duchin, Matsusaka and Ozbas (2010)), such as the RiskMetrics (previously known as IRRC) classification, which considers a director independent if he or she is not an employee, a former executive, a relative of a current corporate executive, or someone who has business relations with the company. ${ }^{2}$ However, even these improved measures of independence are imprecise. In the particular case of banks, this problem is complicated by the fact that some outside directors are representatives of the bank's best clients, and that this information is difficult to obtain. According to Adams (2010, p. 14), “customer-directors are likely to have different incentives and motivations than other outside directors. To correctly measure board independence requires identifying them but this is virtually impossible." Another difficulty is the fact that the formal definition of independence varies across countries.

\footnotetext{
${ }^{2}$ The RiskMetrics director database only covers US firms and thus cannot be used for international comparisons.
} 
We are able to construct a reliable measure of board independence because we have data on bank directors' employment histories, as well as a comprehensive record of fees paid to banks by their corporate clients. We consider a director to be formally independent if he or she (i) is not a current or former employee of the bank, (ii) is not a representative of the bank's employees, (iii) does not represent a firm that has a significant commercial relationship with the bank, and (iv) is classified as independent by the bank. Our definition of independence is a proxy for the alignment of directors' interests with those of shareholders.

Off-the-shelf data on directors' banking experience do not exist; we need to construct them from directors' curriculum vitas. We consider an outside director to have banking experience if the director has held at least one managerial or top-executive position in a bank. From the employment histories of the outside directors in our sample, we obtain a list of previous employers for each director. We match these employers with company identifiers from a number of different datasets. We are then able to infer the industrial classification for most of these companies.

We examine the cross-sectional and time-series dimensions of our sample separately. To make sure that our results are not specific to what happened to banks during the 2007-09 crisis, we use 2006 as our benchmark year in the cross-sectional analysis, but we also check for robustness to alternative years. All of our results are unaffected by the crisis period. Our main findings are as follows.

Countries explain more of the cross-sectional variation in bank board independence than bank characteristics do. While bank-specific characteristics alone explain about $10 \%$ of the variation in bank board independence, country dummies alone can explain up to $54 \%$ of the observed variation. After controlling for country characteristics, the incremental explanatory power of bank-specific variables is just 3\%. These results are very robust; they are not explained by year effects, outlying countries, or by the oversampling of US banks. In 
stark contrast, we find that bank-specific characteristics alone explain $7 \%$ and that country dummies alone explain only $3 \%$ of the cross-sectional variation in bank board experience. That is, most of the cross-sectional variation in board experience is bank specific or idiosyncratic.

Our results lead naturally to the question of why countries matter so much for bank board independence, but not so much for bank board experience. Country characteristics could be related to board characteristics because laws, regulations and institutions can either complement or substitute for internal governance (Doidge, Karolyi, and Stulz (2007); and Aggarwal, Erel, Stulz, and Williamson (2009)). Additionally, the direct and indirect regulation of bank board appointments could also explain why bank board independence varies so much across countries. To investigate these possibilities, we consider three sets of country-specific variables: board regulations, proxies for financial and economic development, and legal-environment variables.

The data provide some support for the importance of board regulations. Although it is not surprising that board regulations can have an effect on board composition, to the best of our knowledge, ours is the first paper that shows evidence linking specific board regulations to board independence across countries.

Countries differ in the extent to which courts can remove directors during the reorganization of troubled banks. In countries where bank directors are less powerful, it should be more difficult or costly to hire outside directors, especially independent ones. Consistent with this view, we find that banks have less independent boards in countries where courts have the right to remove bank directors in reorganizations.

Another one of the few board regulations that can be compared across countries is the requirement that firms are run by a single board, as in the United States, or by two different boards, as in Germany. In the two-tiered structure, the advising and monitoring functions of 
boards are formally separated into a management and a supervisory board (see Adams and Ferreira (2007)). We find strong evidence that banks in countries with mandatory one-tiered structures have boards that are on average more independent. ${ }^{3}$

When considering other country characteristics, we find strong evidence that bank board independence is a "normal" good: countries with higher per capita GDP have banks with more independent boards. However, we do not find robust evidence that financial development and investor protection foster board independence. Thus, there is no clear evidence that banks adjust their board independence levels to reflect the country-wide quality of external governance.

We then turn to the time-series dimension of our sample. We start by showing that bank board independence monotonically increases over time in the pre-crisis period (20002006), with the largest increases occurring around 2002-03 for US banks, and with one year delay for banks outside the US. While independent directors already held $51 \%$ of the board seats in US banks in 2000, in non-US banks the average level of independence was 25 percentage points lower.. The respective figures for 2006 are $74 \%$ and $40 \%$. While independent directors now hold an overwhelming majority of board seats in US banks, independent directors are still in the minority in some other parts of the world.

Although it is not possible to determine the exact causes of these dramatic changes over such a short time period, we note that banks, like all firms, were likely affected by the increase in regulatory pressure on governance issues that culminated in the Sarbanes-Oxley Act (SOX) of 2002. Consistent with this explanation, the increase in board independence over the 2002-03 period is less pronounced for non-US banks, many of which are not directly subjected to SOX regulations. But overall, both US and non-US banks exhibit similar time trends in board independence.

\footnotetext{
${ }^{3}$ We see the rules on one-tiered and two-tiered board structures as a proxy for the overall governance system of a country.
} 
The evolution of the aggregate levels of bank board experience is the mirror image of that of board independence, with average experience decreasing sharply from $28 \%$ in 2002 to $21 \%$ in 2006 . Experience then increases slightly in the crisis years to about $24 \%$ in 2008 (similarly, independence falls from 2006 to 2008). As in the case of board independence, these aggregate patterns in board experience are mostly driven by US banks. In terms of economic significance, the over-time changes in average experience are small: In the US, the largest changes occurred between 2002 and 2005, when experience drops from $22 \%$ to $17 \%$. In non-US banks, experience stays relatively flat throughout the whole period at about $37 \%$.

Lastly, we run firm fixed-effects regressions to control for time-invariant omitted variables and get a more reliable picture of the relationship between bank characteristics and board structure. We consider a set of bank variables that proxy for size, performance, capital structure, and ownership structure. We find that yearly changes in bank characteristics are not related to changes in board independence in a statistically significant way. These results are consistent with the hypothesis that bank-specific characteristics have little impact on board independence. In contrast, we find that changes in firm size (as measured by assets) are robustly and positively related to changes in bank board experience. Another robust finding is that changes in performance variables such as market-to-book and operating performance display a negative relation with changes in board experience.

Overall, the evidence is consistent with the view that banks adjust the composition of their boards to their particular conditions, but only if regulations allow them the freedom to do so. This interpretation of the evidence suggests that board structure can have real consequences for bank performance, as regulation may push banks away from their privately optimal board structures. We believe that our findings can help explain some of the evidence uncovered by a number of recent papers that investigate the link between board characteristics 
and bank performance during the crisis. ${ }^{4}$ Adams (2009) is the first to find suggestive evidence that board independence is positively related to bank bailouts. Minton, Taillard, and Williamson (2010) provide more systematic evidence that board independence - but not financial expertise - predicts the bailouts of financial institutions. Our main contribution is to provide a coherent explanation for why board independence, but not board experience, seems to matter for bank outcomes. By showing that regulation has a substantial impact on independence, but not on experience, we believe that our paper provides a compelling explanation for why the existing evidence linking bank board independence and bank performance is so robust.

Our discussion of the determinants of board structure is limited by the difficulties in establishing causal relations between the variables in our dataset. As we are interested in examining the extent to which board structure is correlated with observable firm and countryspecific variables, determining the ultimate source of such correlations is not our first order concern. In addition, reverse causation is not really a concern in the case of country-specific variables. Although such variables could proxy for omitted ones, these omitted variables must also be country-specific, and thus our conclusions are unchanged.

The remainder of the paper is organized as follows. After reviewing the related literature in Section 1, we describe the data and present summary statistics in Section 2. In Section 3 we analyze the cross-section of board structure. In Section 4 we exploit the timeseries dimension of the sample and we investigate more closely the role of bank characteristics in explaining board structure. We conclude in Section 5.

\footnotetext{
${ }^{4}$ A possibly incomplete list includes Adams (2009), Beltratti and Stulz (2009), Erkens, Hung, and Matos (2010), Chesney, Stromberg, and Wagner (2010), and Minton, Taillard, and Williamson (2010).
} 


\section{Related literature}

Our findings are consistent with some of the existing evidence collected by the international corporate governance literature, such as the finding that most of the crosssectional variation in governance variables is explained by country characteristics. Using samples of mostly non-financial firms, Doidge, Karolyi, and Stulz (2007) and Aggarwal, Erel, Stulz, and Williamson (2009) find evidence that the quality of firm-level governance is increasing in a country's level of economic and financial development and of investor protection. Such empirical relations strongly suggest that country-level governance and firmlevel governance are complements. Our results are similar as they highlight the importance of countries for the governance of banks.

Our work complements the empirical literature on (non-financial) corporate board structures. This literature shows that the composition of boards is related to a number of firm characteristics such as size, growth opportunities, leverage, and proxies for information asymmetry, among others (Boone, Field, Karpoff, and Raheja (2007); Coles, Daniel, and Naveen (2008); Linck, Netter, and Yang (2008); Lehn, Patro, and Zhao (2009); and Ferreira, Ferreira, and Raposo (2011)). There is also evidence that boards of banks are different from those of non-financial firms (Adams and Mehran (2003) and (2008)). Boards of banks may play a more central role in the governance framework. As banks are more opaque than nonfinancial firms (Morgan (2002)), outsiders could face difficulties in assessing risks and properly valuing banks. Under such conditions, external governance mechanisms may not work well, putting additional pressure on the board.

Although our focus is on the potential determinants of board structure, a natural question is whether board structure, and in particular director independence, matters for firm policies and performance. In the context of non-financial firms, there is robust evidence that board composition affects important firm outcomes, such as CEO turnover (Weisbach (1988); 
Adams and Ferreira (2009); and Jenter and Lewellen (2010)). In banks, there is some evidence linking board governance and risk taking (Laeven and Levine (2009)).

Research on the role of bank directors during the recent global financial crisis reveals some surprising results. Adams (2009) finds that US banks with more independent directors were more likely to receive Troubled Asset Relief Program (TARP) money. Minton, Taillard, and Williamson (2010) provide ample evidence that board characteristics in financial institutions are related to a number of performance measures during the crisis. Similarly, Beltratti and Stulz (2009) find that banks with more pro-shareholder boards performed worse, and Erkens, Hung, and Matos (2010) find that financial firms with more independent boards experienced larger losses.

This literature suggests that bank governance does indeed matter, but not necessarily in obvious ways. Fahlenbrach and Stulz (2010) find that banks run by CEOs with large ownership stakes, if anything, performed worse than those with low CEO ownership stakes during the 2007-08 crisis. Cheng, Hong, and Scheinkman (2009) present evidence that a culture of short-term compensation leads to more risk-taking in financial firms, but they argue that such risk taking is consistent with shareholders' goals. This explanation is compatible with findings by Laeven and Levine (2009) that banks with more shareholder-oriented governance structures take more risks.

More generally, the last generation of papers on board structure and firm performance has brought board composition back into the spotlight. These papers use innovative empirical designs to circumvent the endogeneity problems that plague earlier studies. Duchin, Matsusaka and Ozbas (2010) use regulations associated with the Sarbanes-Oxley Act of 2002 as an exogenous source of variation in board independence. In a difference-in-differences estimation, they find that increases in director independence improve performance in those firms in which the costs of obtaining information are low, while performance worsens in firms 
in which information costs are high. ${ }^{5}$ Adams and Ferreira (2009) use instrumental variables methods to estimate the causal effect of board gender diversity on performance. They find that gender diversity improves performance only in firms with many takeover defenses. They also provide evidence that more diverse boards are tougher monitors of managers, validating the use of gender diversity as a proxy for independence. Nguyen and Nielsen (2009) use director sudden deaths as a natural experiment to identify the market value of independent directors. They also find that the value of independent directors varies with firm characteristics and director functions. Overall, all these papers show remarkably consistent results. Director independence matters for firm performance, but its effects are not homogeneous across different companies. To identify such effects, it is necessary to use exogenous sources of variation in board independence and to allow for heterogeneous effects.

The most recent literature provides strong evidence of the importance of board composition. Understanding the determinants of board composition thus merits special attention. We believe that we can only make sense of the evidence that links boards to firm outcomes after a thorough investigation of the determinants of board composition. The evidence is this paper is a step in this direction.

\section{Data and Sample}

Our initial sample consists of an unbalanced panel of 740 publicly-listed banks in 41 countries for the nine-year period from 2000 to $2008 .{ }^{6}$ We have a complete set of directorlevel biographical data for all of our 4,081 bank-year observations. We source our director data from BoardEx. The entire BoardEx database gives us a total of 49,665 director-year

\footnotetext{
${ }^{5}$ Analyzing the direct effect of the 2002 governance rules, Chhaochharia and Grinstein (2007) also find heterogeneous effects of governance rules on firm value.

${ }^{6}$ Our sample is based on all banks available in the BoardEx database, which only includes banks with some public securities. These securities are not necessarily common equity. For an example, of the six Austrian banks in our sample, one (Osterreichische Volksbanken AG) only has non-voting preference shares that are publicly traded.
} 
observations for 12,010 unique directors who have served on the boards of our sample banks between 2000 and 2008.

We define banks as those companies that held a banking license at the end of 2008 . Our sample includes all US investment banks that obtained a banking license as part of the 2008 bailout. We validate our definition of banks by cross-checking it with regulatory listings; we include only those firms that operate within the 60 two-digit SIC code. Our unit of analysis is a bank holding company. Boards of fully-owned subsidiaries are not included. ${ }^{7}$

Table I gives an overview of the distribution of our sample by year and country. The sample is skewed towards both US banks and more recent observations. We have complete data for banks in 31 countries for 2006, which is our benchmark year in the cross-sectional analysis. We use data from 41 countries in 2008. We perform a number of robustness checks to make sure that our results are not driven by these sample imbalances.

$<<$ Table I about here $>>$

BoardEx provides standard biographical information such as age, nationality, and gender for all board members, as well as information about their current and past board positions, including the company's name and director tenure at each position. It also provides information on directors' past non-board positions, income, and educational background (albeit at times incomplete). To construct the banking experience variable, we identified 27,773 companies and non-profit organizations that employed at least one of the 12,010 directors in our sample at some point. We matched the names of these companies with more detailed company-specific information from various alternative databases. To do so, we

\footnotetext{
${ }^{7}$ We treat banks that are part of banking groups as individual companies as long as they issue their own public securities. For example, in Austria we consider each of the banks of the 3 Banken Gruppe as individual banks, because they are listed separately. We use data on ownership structure to control for some of the possible effects of such variables on our results.
} 
developed an algorithm that allowed us to match the names from BoardEx with the population of company names in Compustat. We then manually verified each of the automatic matches, and where applicable linked subsidiaries to the respective parent company. We repeated this process several times with other company databases such as Amadeus, Icarus, Orbis, and Oriana, allowing us to match ever smaller companies. This procedure yields a company identifier for most firms, enabling us to extract a wealth of financial and non-financial data. After internet-researching the remaining firms, we obtain SIC codes for more than $95 \%$ of our sample.

We obtain information on whether directors are also representatives of the banks' most important customers from the Deals Analysis option in the Thomson One Banker database. We downloaded all available information in the M\&A, Equity, Bonds and Loans sections and matched the company names from Thomson One Banker to those in our dataset.

We use these data to construct our director-level variables. Our independence variable classifies a director as independent if all of the following four criteria are met: (1) the director has never been employed by the bank, (2) the director does not represent a firm that has a significant commercial relationship with the bank, (3) the director is not a representative of the bank's employees, and (4) the bank classifies the director as independent. ${ }^{8}$

We construct a banking experience indicator variable that equals one if the director had a prior managerial or top-executive position in any bank. We construct a director busyness variable by counting board positions of each director at each year. We measure board size by the count of all directors per bank-year.

\footnotetext{
${ }^{8}$ In the case of Germany, we do not use criterion (4), as German banks - like all other German companies - do not report the independence of outside directors (Aufsichtsratsmitglieder). This procedure implicitly overstates independence levels, as some unobserved dimensions of independence cannot be taken into account.
} 
To obtain bank financial data, we merge our sample with Worldscope. We use book assets and sales as proxies for bank size. ${ }^{9}$ To control for the various dimensions of bank performance, we use Market-to-Book and Return on Assets (ROA). We calculate market-tobook as the market value of shares over common equity ${ }^{10}$ and ROA as net income over assets. We follow the standard practice in the banking literature of measuring leverage as assets over common equity (e.g. Adrian and Shin (2010)). We obtain share price data from Thomson One Banker.

Previous research finds that the ownership structure of banks matters for bank governance and performance (Caprio, Laeven, and Levine (2007); and Morck, Yavuz, and Yueng (2010)). We collect detailed data on ownership structure. The prime data source of bank ownership data is Bankscope, which has ownership data for 687 banks. For other 12 banks we were able to collect ownership data from Thomson One Banker. This gives us ownership data for 3,905 bank-year observations; 3,870 based on Bankscope data and 35 on data from Thomson One Banker. We have no ownership data for 294 bank-year observations.

Bankscope reports ownership changes on investor level, which give us 101,409 records. We classify the investor type categories reported by Bankscope into the following groups: Employee, Family, Government, Institutional Investor, Financial Institution, and Others. We then fill in the missing observations for those years when no change occurred. We spent considerable time cleaning the data, first on bank-year-investor level and then on bankyear level. One of the problems that we faced was that ownership stakes of business groups are reported multiple times. In this case we use the stake that is attached to the highest level in the group. For better handling of the data, we also exclude ownership stakes of less than $3 \%$. We use the ownership thresholds of $10 \%, 20 \%, 50 \%$ and $100 \%$. We include the $100 \%$

\footnotetext{
${ }^{9}$ Our base currency for assets as well as all other accounting variables is the US dollar (USD). All non-USD denominated values were converted into USD at market exchange rates on the day of announcement. We do not correct assets for inflation as it is unnecessary given that we use the log of assets in the regressions, so that year dummies implicitly capture the effects of inflation.

${ }^{10}$ WS Code 03501.
} 
threshold to separate firms that were taken over, which typically also correspond to the last year of the bank in the sample. For each for the bank-year observation, we construct dummy variables indicating the existence of an ownership block for each of these ownership thresholds. We also create similar indicator variables that discriminate among different types of owners. $^{11}$

We collect many country-specific variables. In line with Doidge, Karolyi, and Stulz (2007), we construct a variable measuring the quality of investor protection (which we call Antidirector) by multiplying the anti-director rights index (the DLLS index) constructed by Djankov et al. (2008) by the rule of law index reported by La Porta et al. (1998). As a robustness check, we construct an alternative investor protection variable by multiplying the anti-director rights index developed by Spamann (2010) by the rule of law index. We do not report results using this alternative measure in the tables, but where appropriate we discuss them in the text. We also collect the credit market regulation index used in Giannone, Lenza, and Reichlin (2010), which we use only in robustness checks.

We use GDP per capita ${ }^{12}$ from the World Bank's World Development Indicators as a proxy for economic development and stock market capitalization over GDP from Euromonitor as a measure of financial development. Our dummy indicating the right of courts to remove board directors in reorganizations comes from the World Bank database on bank regulation and supervisory practices developed by Barth, Caprio and Levine (2008). We also hand-collected data from many sources to construct a dummy variable indicating whether a country has a compulsory one-tiered board structure.

Table II depicts the summary statistics for all variables over the period 2000 to 2008 . The unit of observation is a bank-year. There is considerable variability in bank board characteristics. We observe boards of banks without independent directors, or without any

\footnotetext{
${ }^{11}$ For an analysis of bank ownership around the world, see Morck, Yavuz, and Yueng (2010).

${ }^{12}$ GDP per capita, PPP (constant 2005 international USD). WB code NY.GDP.PCAP.PP.KD.
} 
outside director with banking experience, while on the other hand we see boards that are staffed fully with independent directors, and also some in which all outside directors have some banking background. Similarly, there is substantial variation in board size, ranging from four to 35 members. The spectrum for the average number of board appointments is equally wide, ranging from no other appointment to a board-level average of 15.8 board seats.

$<$ Table II about here $>>$

In our cross-sectional analysis we focus on data from 2006, which is the last year prior to the financial crisis. For that year, our sample contains data from 622 banks and 31 countries. Table III gives a detailed overview of the board structure variables by country. There is considerable variation in board characteristics across countries. In 2006, the minimum board size in our sample is four (a US bank) and the maximum is 34 (a Russian bank). The equally-weighted average of board size across all countries is 15.6; the average board size in the US is $10.7,12.4$ in the UK, and 21.3 in Germany, to give a few examples. Among developed countries, France and Switzerland have very low levels of independence. In contrast, Australia, Canada, and the US exhibit comparatively high levels of director independence.

The equally-weighted cross-country average of the ratio of outside directors with banking experience is $36 \%$. This average however overestimates the number of outside directors with banking experience, as in the US (where most of our sample banks are located) this proportion is just $18 \% .^{13}$

\footnotetext{
${ }^{13}$ A natural question is whether the current level of banking experience among bank directors is inefficiently low. Regulators and policy-makers have recently emphasized the importance of banking experience and financial expertise for outside directors; an example is the Walker (2009) review in the UK. Hau and Thum (2009) find that measures of board competence, including previous banking experience, are positively related to the performance of German banks during the crisis. Cuñat and Garicano (2010) find that chairmen's human capital crucially affected the performance of Spanish savings banks during the crisis.
} 
Some of the countries with high levels of bank board independence - such as Australia, Canada, and the US - exhibit relatively low banking experience ratios. In our sample, 142 banks (23\% of the total) have no outside director with banking experience on their boards. Two banks are fully staffed with outside directors with prior experience in banking and 60 banks (about 10\% of the total) have a majority of such directors. In terms of busyness (the average number of board appointments held by outside directors), we observe values ranging from no other board appointment (in US banks) to 13.6 additional board appointments on average (in one Italian bank). The equally-weighted average across all countries is 4.4 board appointments.

$<<$ Table III about here $>>$

\section{The Cross-Section of Board Independence and Board Experience}

In this section we focus on the cross-sectional variation in board structure. As we have nine years of bank-level data, we focus initially on a representative year. We choose the year of 2006 as the benchmark because the years after the crisis could be atypical, as board structure may have changed as a consequence of the crisis. The crisis period is unusual in that there are sudden changes in bank ownership, widespread financial distress, and ad hoc government intervention. However, we find that the crisis period does not significantly affect the key results.

\subsection{Explaining Variation in Bank Board Structure: Countries versus Firm Characteristics}

How much of the cross-sectional variation in board structure is explained by country effects and firm characteristics? Methodologically, we follow the approach of Doidge, Karolyi, and Stulz (2007) and run linear regressions of board structure variables 
(independence and experience) on firm characteristics and country dummies. We then compare the incremental (adjusted) $\mathrm{R}^{2}$ of each set of explanatory variables. ${ }^{14}$

Specifically, we estimate the following models:

$$
\begin{aligned}
& y_{i j}=\alpha+\boldsymbol{x}_{\boldsymbol{i} \boldsymbol{j}}^{\prime} \boldsymbol{\beta}+u_{i j} \\
& y_{i j}=\boldsymbol{d}_{\boldsymbol{j}}^{\prime} \boldsymbol{\theta}+u_{i j} \\
& y_{i j}=\boldsymbol{x}_{\boldsymbol{i} \boldsymbol{j}}^{\prime} \boldsymbol{\beta}+\boldsymbol{d}_{\boldsymbol{j}}^{\prime} \boldsymbol{\theta}+u_{i j}
\end{aligned}
$$

where $y_{i j}$ is the board structure variable of bank $i$ in country $j, \alpha$ is a constant, $\boldsymbol{x}_{i j}$ is a vector of bank characteristics, $\boldsymbol{d}_{\boldsymbol{j}}$ is a vector of country dummies, $\boldsymbol{\beta}$ and $\boldsymbol{\theta}$ are vectors of parameters to be estimated, and $u_{i j}$ is the error term. Our goal in this section is not make inferences about the estimated parameters but to compare the explanatory power, or goodness of fit, of these three models.

Our main variables of interest are either the fraction of independent directors or the fraction of outside directors with banking experience. As these variables are bounded between zero and one, we use a logistic transformation (also known as the log odds ratio) of the original variable $z_{i j}$ as our dependent variable: $y_{i j}=\ln \left[z_{i j} /\left(1-z_{i j}\right)\right] .{ }^{15}$

We report the results in Tables IV and V. The first three columns of each table show results for board independence regressions and the last three show results for board experience regressions. Because the missing data on ownership variables substantially reduce the 2006 sample size from 609 to 572 banks, we report results both without and with the block holder dummy among the set of controls (Tables IV and V respectively). Column (a) in Table IV shows results for model 1.a, i.e. a regression of board independence on a vector of five firm characteristics: $(\log )$ assets, $(\log )$ sales, $(\log )$ market to book, return on assets, and

\footnotetext{
${ }^{14}$ Rauh and Sufi (2010) employ a similar approach in their investigation of the role of measurement errors in explaining the poor explanatory power of firm and industry characteristics in the cross-section of capital structure.

${ }^{15}$ In practice, this transformation has no important consequences for our results. We transform all bounded dependent variables because not doing so may lead to implausible estimates of marginal effects.
} 
(log) leverage. In that regression, only ROA displays a statistically significant (at $10 \%$ ) relation with board independence. Overall, these five bank characteristics explain $10 \%$ of the total variation in the sample (using the adjusted $\mathrm{R}^{2}$ as the metric). Including additional bankspecific variables (e.g. alternative measures of capital strength, such as the tier 1 capital ratio, or performance, such as sales growth) does not alter the results qualitatively. We choose a parsimonious model specification in order not to lose too many observations due to missing data.

At first sight, bank variables seem to explain only a small fraction of the heterogeneity in board independence. A natural question is whether this is a feature of our empirical design. For example, there could be other bank-specific variables with stronger explanatory power that are omitted from our specification. To put our results into perspective, we compare them with those found in other papers on board independence in non-financial firms. In regressions of board independence on a much larger set of firm-level controls, Linck, Netter, and Yang (2008) report a maximum $\mathrm{R}^{2}$ of $17 \%$. Ferreira, Ferreira, and Raposo (2011) report $\mathrm{R}^{2}$ 's varying from $14 \%$ to $16 \%$, using up to 18 firm-specific variables as regressors. Thus, the relatively low $\mathrm{R}^{2 \text {, }} \mathrm{s}$ in board independence regressions on firm-specific variables is a wellestablished regularity. It seems unlikely that by adding more firm-specific controls we could increase the joint explanatory power of the regressors by much.

Column (b) shows results for model 1.b, i.e. a regression of board independence on a set of country dummies (all dummy coefficients are omitted from the table). This exercise reveals that country dummies alone can explain $54 \%$ of the observed variation in board independence.

$<<$ Table IV about here $>>$ 
Finally, in column (c) we include both bank characteristics and country dummies. The incremental explanatory power of bank characteristics is quite small; the $\mathrm{R}^{2}$ increases by 3 percentage points when moving from (b) to (c). This is in contrast with the large incremental $\mathrm{R}^{2}$ for country dummies: moving from (a) to (c), the $\mathrm{R}^{2}$ increases by 47 percentage points. Country effects can explain much of the observed variation in bank board independence.

A natural question is whether the high $\mathrm{R}^{2}$ associated with country dummies is mechanically driven by the fact that some countries only have a few banks in the sample. This is not the case. Even if we drop from the sample all countries with fewer than 5 banks, we still obtain an adjusted $\mathrm{R}^{2}$ of $41 \%$ for model 1.b. This is a very conservative approach, as it leaves us with only 12 country dummies for 581 observations. On the other extreme, dropping the US leaves us with only 116 observations and an adjusted $\mathrm{R}^{2}$ of $28 \%$ for model $1 . \mathrm{b}^{16}$ Instead of dropping all US banks, we also run a regression in which we keep only 15 randomly selected US banks. This regression yields an adjusted $\mathrm{R}^{2}$ of $34 \%$ for model 1.b. Thus, homogeneity among US banks seems to be more important for the high explanatory power of country dummies than the presence of small outlying countries. We thus conclude that the importance of countries for board independence is real; it is not just a feature of how the sample is constructed.

We also find very similar results if we consider alternative years. For example, if we use the year 2008 (620 banks from 41 countries), we obtain an adjusted $\mathrm{R}^{2}$ the models 1.a to $1 . \mathrm{c}$ of $12 \%, 53 \%$, and $52 \%$ respectively.

Overall, our results suggest that while bank characteristics can explain little of the observed variation in board independence, country-specific characteristics account for a large

\footnotetext{
${ }^{16}$ Adjusted $\mathrm{R}^{2}$ s are not comparable across samples of substantially different sizes because the ad hoc penalty for adding more regressors is relatively more important when the sample is small. For example, the non-adjusted $\mathrm{R}^{2}$ for model 1.b when the US is dropped is $47 \%$, while it is $56 \%$ in the full sample. Adjusting the $\mathrm{R}^{2}$ yields a penalty of 20 percentage points in the former case but only a 2 percentage point penalty in the latter case.
} 
fraction of that variation. We now address the question of whether the same applies to board experience.

In Table IV, columns (d)-(f), we report the results of estimating models 1.a-c for the (logistic transformation of the) percentage of outside directors with banking industry experience. These results are in sharp contrast with those of board independence. Bank characteristics can explain only $7 \%$ of the total variation in board experience, while country dummies alone account for just 3\%. From column (f) we conclude that most of the variation in the proportion of directors with banking experience cannot be explained by variation in observed characteristics; the adjusted $\mathrm{R}^{2}$ for the model $1 . c$ regression is only $5 \%$. While there is substantial variation in director banking experience, this variation is not explained by countries or by some of the most salient bank-specific characteristics, with the notable exception of firm size. ${ }^{17}$

Our independence variable is comparable across countries because most of the criteria that we use to define independence are not country-specific. Although we never consider a director independent simply because the bank has classified them as such, we do consider a director as non-independent if the bank does not classify the director as independent. We believe that our approach is conservative, as banks are more likely to overstate independence rather than understate it. However, this approach has potential drawbacks, because bank selfreporting of independence could be country specific. In particular, in some countries, directors are not considered independent if they are representatives of some of the bank's major shareholders. Thus, differences in ownership structures across countries could explain our results, as countries with large block holders could display low levels of independence. We thus need to investigate the effect of ownership structures on board independence.

\footnotetext{
${ }^{17} \mathrm{We}$ obtain similar results if we measure experience in the financial services industry more broadly.
} 
Ownership variables feature prominently in previous papers on banks around the world (Caprio, Laeven, and Levine (2007); and Morck, Yavuz, and Yueng (2010)). As a first step to investigate the importance of ownership variables, in Table V we redo the analysis above including the block holder ownership dummy (using the $10 \%$ threshold) in the set of controls. Despite the loss of 37 observations, the results are basically the same: country dummies matter substantially for board independence, but not for board experience. The presence of a block holder is associated with less independence, but this association is not statistically significant once country dummies are included in the regression. Block holders are also associated with lower banking experience.

In unreported regressions, we also analyze the importance of ownership structures in more detail by replacing the block holder dummy with a set of six dummies describing the type of the largest block holder (if there is one): Financial institutions, institutional shareholders, governments, families, employees, and others. Of these variables, only block ownership by either families or employees are robustly (negatively) related to board experience. None of the block holder type dummies is robustly related to board independence.

We conclude that countries are more important for understanding the cross-section of board independence than are bank characteristics. In contrast, neither country characteristics nor observed bank characteristics are good predictors of banking industry experience of outside directors. The potential links between ownership concentration and board independence cannot explain the importance of country effects for board independence.

\subsection{Estimating Country Effects}

Given that countries matter so much for board independence, a natural question is: Which countries have high levels of board independence? Table III shows the average board independence levels for the 31 countries in our 2006 sample. There is substantial variation in 
board independence across countries. While countries such as the US and Canada display levels of bank board independence at about $74 \%$, countries such as Spain, Sweden and the UK have independence levels in the 40-50\% range, and countries such as Argentina, Denmark and France are in the $10-30 \%$ range.

These numbers are interesting but difficult to interpret because for most countries our sample size is small. In fact, US banks represent $80 \%$ of the whole sample in 2006. This sample imbalance creates two problems. First, with few observations per country, country effects cannot be estimated with much precision. Second, differences in bank characteristics across countries may explain some of the cross-country variation in board independence.

There is nothing we can do with respect to the first problem, as it is simply a limitation of the available data. The small sample sizes in most countries other than the US are not just a consequence of better availability of US data; they are mainly due to the fact that most countries have few publicly-traded banks. As our goal here is to describe the data given our sample, the small sample sizes in some countries only mean that we should attach less confidence to their estimated country effects.

The second problem is more important. For example, comparing the average board independence in Belgian banks with the average board independence in US banks can be seriously misleading if the three Belgian banks in our 2006 sample are very different from the typical US bank. Any observed differences in independence could be attributed to Belgian banks being different rather than to the location of these banks in Belgium. One solution is to estimate country effects as the coefficients on the country dummies in regressions that include firm controls, as the ones in Table IV. The problem is that, with few observations per country, country effects are likely to be overestimated for those countries with few banks in the 
sample. ${ }^{18}$ To address this problem, we use an alternative approach. We estimate countryspecific effects by means of a matching procedure in which non-US banks are matched with US banks that have similar observable characteristics.

Our procedure is as follows. Let $j \in\{1, \ldots, N\}$ index the $N$ countries in our sample, with the convention that $j=1$ denotes the US. Let $z_{i j}$ be the board structure variable for bank $i$ in country $j$ and let $\boldsymbol{x}_{i j}$ be a vector of observable bank characteristics (covariates). We match each bank $i$ from country $j \neq 1$ with a US bank with observable characteristics similar to $\boldsymbol{x}_{i j}$. We then compute the effect of country $j \neq 1$ as

$$
c_{j}=\bar{z}_{j}-\bar{z}_{j m}
$$

where $\bar{z}_{j}$ is the average level of the board characteristic (independence or experience) in country $j$ and $\bar{z}_{j m}$ is the respective average among matching US banks.

This matching approach allows us to make meaningful comparisons by benchmarking non-US banks against observationally similar US banks. Such an approach is implementable even when country samples are small, which is an important concern in our application. If the assumptions underlying the matching procedure hold, we can estimate meaningful country effects even for countries with only one bank. As these estimates can be imprecise, we refrain from making strong statements about their importance.

We implement this method by matching banks on propensity score. ${ }^{19}$ Using the full sample, we first estimate the parameters of a Probit model as in

$$
p\left(\boldsymbol{x}_{\boldsymbol{i j}}\right) \equiv \operatorname{Prob}\left(Y_{i j}=1 \mid \boldsymbol{x}_{\boldsymbol{i j}}\right)=\Phi\left(\boldsymbol{x}_{\boldsymbol{i j}}^{\prime} \boldsymbol{\beta}\right)
$$

where $Y_{i j}$ is a 'treatment' variable that takes the value of 1 if bank $i$ is from the US (i.e. if $j=1), \boldsymbol{\beta}$ is a vector of parameters to be estimated, and $\Phi$ is the standardized normal

\footnotetext{
${ }^{18}$ To see this intuitively, consider the extreme case in which there is only one bank per country. In such a case, the country dummy in a cross-sectional regression explains the independence level perfectly. Our matching approach allows us to circumvent this problem and produce meaningful estimates of country effects even when there is only one bank in a country. Obviously, this approach relies on somewhat strong assumptions.

${ }^{19}$ This is similar to the approach of Aggarwal, Erel, Stulz, and Williamson (2009).
} 
cumulative distribution function. The probability of receiving treatment conditional on the covariates is the propensity score, $p\left(\boldsymbol{x}_{\boldsymbol{i} \boldsymbol{j}}\right)$. We then match each non-US bank with a US bank on the basis of their estimated propensity scores.

We use five bank characteristics in the matching procedure: (log) assets, (log) sales, (log) market to book, return on assets, and (log) leverage. For each non-US bank, we define the matching bank as the US bank whose propensity score is the closest (in absolute terms) to that of the non-US bank. ${ }^{20}$ To obtain an estimate of (2), we calculate the difference between the board structure variable of each non-US bank and their matched US bank, and then average this difference by country. ${ }^{21}$

We call the difference between the average of country $i$ 's independence levels and those in the matching sample the independence gap of country $i$. A negative gap means that the country has a lower level of board independence than what is observed in similar US banks (by construction, the US has an independence gap of zero). In Table VI, for each country we present four estimates of their independence gap: columns (a) and (b) report gaps obtained after banks are matched on their characteristics and columns (c) and (d) report results obtained by a naive approach (no matching). In columns (b) and (d), we use selfreported levels of independence rather than our independence measure.

$<<$ Table VI about here >>

Table VI shows many interesting results. First, comparisons between columns (a) and (c) reveal that matching may either reduce (in 18 cases) or increase (in 12 cases) the

\footnotetext{
${ }^{20}$ As a robustness check, we also match each non-US bank with the two US banks with propensity scores that are the closest from above and below (provided both exist). The results using this alternative procedure are qualitatively similar from the ones obtained with the simpler closest neighbor approach.

${ }^{21}$ This approach can be formally justified under the assumption that a non-US bank, if it was located in the US, would have the same expected level of the board structure variable as a US bank with similar characteristics. This is a version of what Imbens and Wooldrige (2009) call unconfoundedness assumption.
} 
differences in board independence between US and non-US banks. A second finding is that there is much cross-country variation in bank board independence. Notably, only Canada appears to have a substantial edge over the US; in Canada, boards are more independent than those in similar US banks by 21 percentage points. This effect arises because the matching procedure benchmarks Canadian banks against a group of US banks that have very low independence levels, which highlights the importance of matching on bank characteristics. At the other end of the spectrum, there are many countries with bank board independence gaps of $-40 \%$ or less, including France (-67\%), Greece $(-46 \%)$, Brazil (-67\%), Russia $(-79 \%)$, and Switzerland (-42\%), among others.

A third important finding is that, overall, most countries display an independence deficit with respect to the US. In all but three cases (Austria, Canada, and Puerto Rico), measured gaps (in column (a)) are negative. Although the small sample sizes in most countries do not allow for testing each country effect in isolation, we can test for whether there is a significant US effect. Using the whole sample of non-US and matched US banks, we find that the US effect is about $26 \%$, an effect that is both statistically and economically significant. This number suggests that a randomly chosen non-US bank from our sample would have its independence level increased by 26 percentage points on average if it was to move its headquarters to the US. This large US effect - being net of observable bank characteristics - strongly suggests that the institutional and business environments in the US differ markedly from those in other countries.

A final lesson from this analysis is the importance of using a measure of independence that is not based only on self-reporting by banks. In columns (b) and (d), Table VI, we report the estimated independence gaps using the self-reported independence levels. We find that the US banks in the matching sample have lower levels of independence on average if we use our definition of independence instead. For example, using the self-reported independence 
variable, Canadian banks display a gap of only $4 \%$; this gap jumps to $21 \%$ if we use our measure of independence.

In sum, when estimating the effects of countries on bank board independence, it is important: (1) to take bank characteristics into account and (2) to use a definition of independence that is (more) consistent across countries. Once both issues are considered, the measured independence gap between US and non-US banks falls, but it is still quite large at about $26 \%$. A fair amount of heterogeneity across countries is hidden behind this average effect, with independence gaps varying from $21 \%$ to $-87 \%$.

For completeness, we also estimate country effects for board experience, despite the fact that our previous results reveal that these effects can only explain a trivial part of the cross-sectional variation in board experience. Table VII reports the results of a matching procedure similar to the one reported in Table VI. Only six countries display negative experience gaps with respect to the US; in most countries, directors with banking experience represent a larger fraction of outside directors than they do in US banks. The average experience gap between non-US and US banks is $17 \%$.

$<<$ Table VII about here $>>$

\subsection{Why do countries matter so much for bank board independence?}

Our results suggest that countries have a substantial influence on bank board structure and that their importance is disproportionately higher for independence than they are for experience. In this section we address the question of why countries matter so much for bank board independence.

One possibility is that stronger governance at the bank level is complementary to stronger investor protection at the country level. Using samples of mostly non-financial 
firms, Doidge, Karolyi, and Stulz (2007) and Aggarwal, Erel, Stulz, and Williamson (2009) find evidence of such complementary effects: the quality of firm-level governance is increasing in a country's level of investor protection.

Related to the previous point is the possibility that board independence is higher in countries with more developed capital markets. This effect could again be a consequence of complementarities between internal governance and country-level governance, as financial development is likely to be associated with better investor protection. Independent directors could also be easier to find in countries with more publicly-listed firms.

Other possible explanations for the importance of countries include idiosyncrasies in business practices across countries (e.g. business culture) and differences in laws and regulations. Laws and regulations can have direct effects on board composition. For example, the Sarbanes-Oxley Act of 2002 has effectively increased the demand for independent directors by requiring audit committees to be entirely composed of independent directors. ${ }^{22}$ Laws and regulations can also affect board composition indirectly, for example by redefining directors' fiduciary duties and liabilities. These duties and liabilities can affect companies' perceptions of the costs associated with hiring independent directors.

To test these explanations, we use country-specific variables that capture some of these possibilities. We note however that none of these explanations are mutually exclusive. We estimate the following model:

$$
y_{i j t}=\boldsymbol{x}_{i j t}^{\prime} \boldsymbol{\beta}+\boldsymbol{h}_{\boldsymbol{j}}^{\prime} \boldsymbol{\delta}+\boldsymbol{p}_{\boldsymbol{t}}^{\prime} \boldsymbol{\gamma}+u_{i j t}
$$

where $y_{i j t}$ is the board structure variable for bank $i$ in country $j$ in year $t, \boldsymbol{x}_{i j t}$ is a vector of bank characteristics, $\boldsymbol{h}_{\boldsymbol{j}}$ is a vector of country characteristics, $\boldsymbol{p}_{\boldsymbol{t}}$ is a vector of year dummies, $\boldsymbol{\beta}, \boldsymbol{\delta}$ and $\boldsymbol{\gamma}$ are vectors of parameters to be estimated, and $u_{i j t}$ is the error term. Because our goal is to make inferences about the estimated parameters, in particular $\boldsymbol{\delta}$, to facilitate the

\footnotetext{
${ }^{22}$ This rule has been in place for NYSE and Nasdaq listed firms since 1999.
} 
comparison with previous results we choose to work both with the 2006 sample only with clustered standard errors by country and with the whole sample up to and including 2008, in which case we estimate (5) by pooled OLS. We include year dummies to account for year effects.

To proxy for the quality of investor protection, in the vector of country characteristics $\boldsymbol{h}_{\boldsymbol{j}}$ we include the anti-director index times the rule of law index. We choose this variable to facilitate the comparison with the existing literature, in particular with Doidge, Karolyi, and Stulz (2007) and Aggarwal, Erel, Stulz, and Williamson (2009). To proxy for the level of financial development, we use the country's stock market capitalization over GDP. We use per capita GDP to proxy for the level of economic development. We also include dummies indicating three different legal origins: English (the omitted dummy), German, and French.

To address whether regulation affects board composition more directly, we use two variables that are particularly relevant for board structure. The first one is an indicator of whether courts are allowed to remove directors from the boards of banks, in cases of reorganization. Although in virtually all countries in our sample (Germany is the exception) regulators have the right to remove bank directors, whether courts enjoy the same right shows more variation across countries. We hypothesize that this variable captures the extent to which bank board composition can be influenced by courts. This is the only variable we are aware of that is specific to the board composition of banks and widely available.

Our second board regulation variable is a dummy indicating whether a country has a mandatory one-tiered board structure. This is a regulation that affects board structures directly. We note however that this variable indicates the requirement of a one-tiered board for all companies, not only banks.

Table VIII displays the results. As before, we report regressions with and without ownership dummies. Results are very similar in both cases, thus we focus on the regressions 
that do not include ownership variables, as these are run in a larger sample. In columns (a) and (b), we report the results for regressions that use the (logistic transformation of the) fraction of independent directors as the dependent variable. We first note that, although replacing country dummies with country characteristics expectedly reduces the adjusted $\mathrm{R}^{2}$, the country characteristics model in (5) does a reasonably good job in fitting the data, with an adjusted $\mathrm{R}^{2}$ of $42 \%$.

Table VIII shows that a reliable association between bank board independence and investor protection does not exist. Thus, we find no evidence of complementarities between bank board independence and country-level governance. This interpretation is strengthened by the lack of a statistically robust relation between French Civil Law legal origin and board independence. Previous works on legal origins usually find that French legal origin countries have lower levels of investor protection.

$<<$ Table VIII about here $>>$

Spamann (2010) develops an alternative measure of anti-director rights and argue that the DLLS measure (the one that we use in Table VIII) is flawed in important ways. To investigate whether our results are driven by the choice of investor protection variable, we redo our analysis using Spamann's index. We find virtually identical results, thus we omit the tables to save space. $^{23}$

If board independence was complementary to country-level governance, we would expect to find a positive relation between financial development and board independence. For example, Aggarwal, Erel, Stulz, and Williamson (2009) document positive correlations

\footnotetext{
${ }^{23}$ Because the Spamman index is missing for six countries in our 2006 sample, we fill in the missing data with the DLLS index. We re-scale the Spamman index to the DLLS scale. Using this measure, the investor protection variable enters with a positive coefficient in both specifications, with low $t$-statistics below 0.8 . We conclude that, at least in our case, the lack of a robust association between investor protection and bank board independence is not driven by the particular choice of investor protection indices.
} 
between financial development and firm-level governance, while Doidge, Karolyi, and Stulz (2007) find similar but weaker results. Table VIII reveals that financial development seems to be negatively related to bank board independence, but this association is not statistically robust. Overall, our evidence suggests that the importance of countries for bank board independence is not driven by a complementarity (nor a substitution) effect between internal and external governance.

In contrast to financial development, economic development (measured by per capita GDP) is positively related to board independence in a statistically robust manner. The mechanism linking economic development to board independence is not clear. One possibility is that the business and regulatory environments of countries in similar stages of economic development share common features.

Our most original results concern the board regulation variables. Bank board independence is lower in countries where courts are legally allowed to remove bank directors during reorganization procedures. Bank board independence is significantly higher in countries with mandatory one-tiered board structures. ${ }^{24}$

Statistical significance alone cannot tell us whether the effects of these regulation variables are large enough to explain the country effects. In Subsection 3.2, we estimate an average independence gap of $26 \%$. From Table III, we see that changes of 50 percentage points in average independence between two countries are not uncommon. Thus, countryspecific variables must be able to explain changes in independence ratios of similar magnitudes if they are to explain the large $\mathrm{R}^{2}$ found in Subsection 3.1.

The economic significance of the regulation variables is substantial. Column (a) shows that countries with empowered courts have independence log odds ratios that are 1.45 lower

\footnotetext{
${ }^{24}$ In recent work, Giannone, Lenza, and Reichlin (2010) report that an index of credit market regulation seems to be the key predictor of country performance during the crisis. In unreported results, we include this index among the set of country characteristics. This index is negatively correlated with both board independence and board experience, but these correlations are never statistically significant; the $t$-statistics are always below 0.8 . Including this index reduces the sample due to missing data but does not change the results qualitatively.
} 
than countries without empowered courts. To translate this effect into a change in independence ratios we need to choose an initial independence level, as the marginal effects are not constant. For example, a bank with $67 \%$ independence (the overall average in 2006) has a log odds ratio of 0.71 . An increase of 1.4 in the log odds ratio brings this bank close to $90 \%$ independence, while a decrease of the same magnitude yields an independence ratio of $33 \%$. An independence ratio of $67 \%$ may be a reasonable benchmark for North America but is too high for most countries. If we use a benchmark of $50 \%$ independence (about the average value for Holland), an increase of 1.4 amounts to $81 \%$ independence, while a decrease of the same magnitude amounts to $20 \%$ independence. As the estimated coefficients for the one-tier dummy are larger (in the 2.2 to 3.1 range), their effects are even stronger. ${ }^{25}$

In sum, we find no evidence that bank board independence is chosen so that it complements external governance at the national level. In contrast, we find direct evidence that board independence is related to board regulations that vary across countries. The magnitude of these effects is substantial. Thus, our tentative conclusion is that laws and regulations that are specifically targeted to board structures can partly explain the large country effect on bank board independence.

For director experience, only financial development and the legal origin variables appear to matter in a robust manner. There is also some weak evidence that countries with one-tiered board structures have boards with less banking expertise.

We conclude that countries matter so much for bank board independence in part because there are some board regulations that vary across countries. These regulations seem to have an important effect on bank board independence, but somewhat relatively less so on director banking expertise. For board experience, country effects are relatively less important.

\footnotetext{
${ }^{25}$ The incremental $\mathrm{R}^{2}$ of the two board regulation variables is about $5 \%$.
} 


\section{The Evolution of Board Structures}

In this section we exploit the time-series dimension of our data to understand the evolution of bank board structures. We first look at the aggregate trends and then we consider how banks change their boards when bank characteristics change.

\subsection{Trends in Board Independence and Experience: The Importance of Year Effects}

Inspection of the time series trend for our key variables reveals that, around 2002 and 2003, the fraction of independent directors considerably increases, while the fraction of outside directors with banking experience decreases (see Figure 1).

$<<$ Figure 1 about here $>>$

Especially for board independence, these changes are substantial: independence levels increase from about $40 \%$ in 2000 to a plateau of about $67 \%$ in $2004-2006$. We see a small decline in board independence in the crisis years (2007-08). In Figure 2, we normalize both variables to 100 in the year 2000 . We can then see even more clearly the magnitude of the relative changes occurring around 2002. These changes are indeed substantial for both variables, but they are particularly dramatic for independence: in 2006, average independence is $70 \%$ higher than it was in $2000 .^{26}$

<< Figure 2 about here $>>$

We do not know why bank board independence increases so much and so quickly. We note however that changes in the regulatory environment such as the Sarbanes-Oxley Act

\footnotetext{
${ }^{26}$ Our trend figures use the whole sample, which is unbalanced. The pattern that we observe is not due to composition effects though; we find basically the same results if we use only data for those banks for which data are available for all years.
} 
(SOX) of 2002 coincide with the period of the most dramatic changes in board structure. ${ }^{27}$ Figures 3 and 4 show that the increase in board independence over the 2002-03 period is less pronounced for non-US banks, but also that both US and non-US banks exhibit similar time trends in independence and size.

\author{
$<<$ Figure 3 about here $>>$ \\ $<$ Figure 4 about here $>>$
}

The evolution of aggregate levels of bank board experience is the mirror image of that of board independence, with average experience decreasing sharply from $28 \%$ in 2002 to $21 \%$ in 2006. Experience then increases slightly in the crisis years to about $24 \%$ in 2008. Figures 3 and 4 show that year effects in board experience are mostly driven by US banks. In non-US banks, experience stays relatively flat throughout the whole period at about $37 \%$.

The data suggest that year effects are important and can explain much of the evolution of board independence and board experience. Aggregate levels of board independence and experience are negatively correlated and appear to be affected by shocks such as the Sarbanes-Oxley Act of 2002 and the financial crisis of 2007-08.

\title{
4.2. Changes in Bank Characteristics and Changes in Board Structure
}

If regulation is an important determinant of board independence, one may wonder whether board composition in banks is set optimally. Although there is no empirical design that can satisfactorily address this issue, we can investigate the link between bank characteristics and board structures in more detail. One possibility is that regulatory effects

\footnotetext{
${ }^{27}$ NYSE and Nasdaq implemented changes in their listing requirements between 1999 and 2003 which, together with SOX regulations, were likely to affect the demand for independent directors.
} 
are so important that bank characteristics become irrelevant for board structure. Or it could also be that regulations affect banks differently depending on bank characteristics.

To shed some light on these issues and to provide a broader picture of the bank-level determinants of board structure, we estimate the following model:

$$
y_{i j t}=\boldsymbol{x}_{\boldsymbol{i j t}}^{\prime} \boldsymbol{\beta}+\boldsymbol{p}_{\boldsymbol{t}}^{\prime} \boldsymbol{\gamma}+f_{i j}+u_{i j t}
$$

where $y_{i j t}$ is the board structure variable for bank $i$ in country $j$ in year $t, \boldsymbol{x}_{i j t}$ is a vector of bank characteristics, $\boldsymbol{p}_{\boldsymbol{t}}$ is a vector of year dummies, $\boldsymbol{\beta}$ and $\boldsymbol{\gamma}$ are vectors of parameters to be estimated, $f_{i j}$ is a unobservable time-invariant bank-specific effect, and $u_{i j t}$ is the error term. We estimate (6) by fixed-effects methods.

We used our whole panel (2000 to 2008) to exploit fully the times-series and crosssectional variation in our sample. The fixed effects eliminate the impact of time-invariant bank characteristics, including country-specific effects. One possible concern is that year effects are important. To estimate (6), our identifying assumption is that, as long as the underlying relationship between bank characteristics and board structure remains stable over time, year dummies can capture the effects of the crisis and other year effects. To check whether this assumption is reasonable, we also estimate (6) using the 2000-2006 sample. We find very similar results, thus we omit the tables for brevity. ${ }^{28}$

Table IX displays the results of the fixed-effects regressions. In column (a) we report the results for a regression that uses the (logistic transformation of the) fraction of independent directors as the dependent variable. We find no statistically reliable evidence that within-bank changes in observable characteristics are related to changes in bank board independence. The high $\mathrm{R}^{2 \text { s }} \mathrm{s}$ in all these regressions are mostly due to the inclusion of bank fixed effects.

\footnotetext{
${ }^{28}$ When using the 2000-2006 sample we find similar estimated coefficients but often higher standard errors (with few exceptions), which is to be expected due to the smaller sample.
} 
This evidence does not imply that board independence does not change over time. We know from the previous subsection that board independence does change substantially over time in our sample; these changes are captured by the year dummies. But these yearly changes in board independence do not appear to be driven by changes in bank characteristics. Rather, they seem to be a response to changes in the institutional environment that affects all banks similarly.

$<<$ Table IX about here $>>$

The results for bank experience are again different. Column (b) shows that, as banks become larger (as measured by assets), board banking experience increases, a result that is very robust. Additionally, as market-to-book ratios decrease, board experience increases. In columns (c) and (d), the block holder dummy is added to the set of regressors. There is no important effect driven by this variable (as it does not change much over time), but there are some minor effects on the results due to the change in the sample. The effect of assets is about the same. The effect of market-to-book is virtually unchanged (the absolute value of the point estimate falls from 0.365 to 0.301 ), although it becomes significant only at $10 \%$ in the smaller sample. ROA now seems to matter, again consistent with the hypothesis that more experienced directors are more likely to be added (or retained) after poor performance. Finally, we find that leverage is negatively related to board experience in the smaller sample.

Overall, we find that there is sufficient over-time variation in board experience, and that this variation is associated with changes in observable bank characteristics, especially size and performance. These results contrast with the relative insensitivity of board independence to changes in bank characteristics. 


\section{Final remarks}

We assemble the most complete data set on boards of banks to date. Our data allow us to draw a detailed picture of bank board composition up to and including the crisis period. The data reveal a number of new empirical facts. Our evidence suggests that bank board independence around the world is mostly determined by regulatory pressure and by factors external to banks. In contrast, the level of previous banking experience among outside bank directors is mostly explained by bank characteristics. Overall, our findings raise the question of whether board regulation helps or hinders bank governance. We see this as a promising agenda for future research.

\section{REFERENCES}

Adams, Renée, 2009, Governance and the Financial Crisis. ECGI - Finance Working Paper No. 248.

Adams, Renée, 2010, Governance of Banking Institutions. Forthcoming as chapter 24 in R. Anderson and H.K. Baker (eds.): Corporate Governance, Wiley \& Sons.

Adams, Renée, and Daniel Ferreira, 2007, A Theory of Friendly Boards. Journal of Finance $62,217-250$.

Adams, Renée, and Daniel Ferreira, 2009, Women in the Boardroom and their Impact of Governance and Performance. Journal of Financial Economics 94, 291-309.

Adams, Renée, and Hamid Mehran, 2003, Is Corporate Governance Different for Bank Holding Companies? Economic Policy Review 9, 123-142.

Adams, Renée B., and Hamid Mehran, 2008, Corporate Performance, Board Structure and its Determinants in the Banking Industry. Federal Research Board of New York Staff Report No. 330.

Adrian, T., and H. S. Shin, 2010, Liquidity and Leverage. Journal of Financial Intermediation $19,418-437$. 
Aggarwal, Reena, Isil Erel, René Stulz, and Rohan Williamson, 2009, Differences in Governance Practices between U.S. and Foreign Firms: Measurement, Causes, and Consequences. Review of Financial Studies 22, 3132-3169.

Barth, J. R., G. Caprio, and R. Levine, 2008, Bank Regulations are Changing: For Better or Worse? World Bank Policy Research Working Paper (WP4646).

Beltratti, A. and R. Stulz, 2009, Why Did Some Banks Perform Better During the Credit Crisis? A Cross-Country Study of the Impact of Governance and Regulation. Working paper, Bocconi University and The Ohio State University.

Boone, Audra, Laura Field, Jonathan Karpoff, and Charu Raheja, 2007, The Determinants of Corporate Board Size and Composition: An Empirical Analysis. Journal of Financial Economics 85, 66-101.

Caprio, Gerard, Luc Laeven, and Ross Levine, 2007, "Governance and Bank Valuation." Journal of Financial Intermediation 16, 584-617.

Cheng, Ing-Haw, Hong, Harrison G. and Scheinkman, José A., 2009, Yesterday’s Heroes: Compensation and Creative Risk-Taking. Working paper, Michigan and Princeton.

Chesney, Marc, Jacob Stromberg, and Alexander F. Wagner, 2010, Risk-taking Incentives, Governance, and Losses in the Financial Crisis. Swiss Finance Institute Research Paper Series $\mathrm{N}^{\circ} 10-18$.

Chhaochharia, V., and Y. Grinstein, 2007, Corporate Governance and Firm Value: The Impact of the 2002 Governance Rules. Journal of Finance 62, 1789-1825.

Coles, Jeffrey, Naveen Daniel, and Lalitha Naveen, 2008, Boards: Does One Size Fit All? Journal of Financial Economics 87, 329-356.

Cuñat, V., and L. Garicano, 2010, Did Good Cajas Extend Bad Loans? Governance, Human Capital and Loan Portfolios. Forthcoming in The Crisis of the Spanish Economy, edited by S. Bentolila, M. Boldrin, J. Díaz Jiménez, and J.J Dolado. 
Dittmann, I., Ernst Maug, and Christoph Schneider, 2010, Bankers on the Boards of German Firms: What They Do, What They Are Worth, and Why They Are (Still) There. Review of Finance 14, 35-71.

Djankov, S., R. La Porta, F. Lopez-de-Silanes, and A. Shleifer, 2008, The Law and Economics of Self-dealing. Journal of Financial Economics 88, 430-465.

Doidge, C., A. Karolyi, and R. Stulz, 2007, Why Do Countries Matter so Much for Corporate Governance? Journal of Financial Economics 86, 1-39.

Duchin, Ran, John G. Matsusaka, and Oguzhan Ozbas, 2010, When Are Outside Directors Effective? Journal of Financial Economics 96, 195-214.

Erkens, David, Mingy Hung, and Pedro Matos, 2010, Corporate Governance in the 2007-2008 Financial Crisis: Evidence from Financial Institutions Worldwide. Working paper, University of Southern California.

European Commission, 2010, Corporate Governance in Financial Institutions and Remuneration Policies. Green paper available at: http://ec.europa.eu/internal_market/company/modern/corporate_governance_in_financial_inst itutions_en.htm

Fahlenbrach, R, and R. Stulz, 2010, Bank CEO Incentives and the Credit Crisis. Journal of Financial Economics, forthcoming.

Ferreira, Daniel, Miguel Ferreira, and Clara Raposo, 2011, Board Structure and Price Informativeness. Journal of Financial Economics 99, 523-545.

Giannone, Domenico, Lenza, Michele and Reichlin, Lucrezia, 2010, Market Freedom and the Global Recession. ECGI - Finance Working Paper No. 288/2010.

Hau, Harald, and Marcel Thum, 2009, Subprime Crisis and Board (in-)Competence: Private vs. Public Banks in Germany. Economic Policy 24, 701-751.

Imbens, Guido, and Jeffrey Wooldridge, 2009, Recent Developments in the Econometrics of Program Evaluation. Journal of Economic Literature 47, 5-86. 
Jenter, Dirk, and Katharina Lewellen, 2010, Performance-induced CEO Turnover. Working paper, Stanford and Dartmouth.

Kirkpatrick, Grant, 2009, The Corporate Governance Lessons from the Financial Crisis. Financial Markets Trends 96:2009/1.

La Porta, R., F. Lopez-De-Silanes, A. Shleifer, and R. Vishny, 1998, Law and Finance. Journal of Political Economy 106, 1113-1155.

Laeven, L. and R. Levine, 2009, Corporate Governance, Regulation, and Bank Risk Taking. Journal of Financial Economics 93, 259-275.

Lehn, K.M, S. Patro, and M.X. Zhao, 2009, Determinants of the Size and Composition of US Corporate Boards: 1935-2000. Financial Management 38, 747-780.

Linck, James, Jeffry Netter, and Tina Yang, 2008, The Determinants of Board Structure. Journal of Financial Economics 87, 308-328.

Minton, Bernadette A., Jérôme P. A. Taillard, and Rohan Williamson, 2010, Do Independence and Financial Expertise of the Board Matter for Risk Taking and Performance? Working paper, The Ohio State University, Boston College, and Georgetown University.

Morck, Randall, M. Deniz Yavuz, and Bernard Y. Yeung, 2010, Banking System Control, Capital Allocation, and Economy Performance. Journal of Financial Economics, forthcoming.

Morgan, Donald P., 2002, Rating Banks: Risk and Uncertainty in an Opaque Industry. American Economic Review 92, 874-888.

Nguyen, Bang Dang, and Kasper Meisner Nielsen, 2009, The Value of Independent Directors: Evidence from Sudden Deaths. Journal of Financial Economics, forthcoming.

Rauh, Joshua D. and Sufi, Amir, 2010, Explaining Corporate Capital Structure: Product Markets, Leases, and Asset Similarity. Working paper, Northwestern U. and U. of Chicago.

Spamann, H., 2010, The "Antidirector Rights Index" Revisited. Review of Financial Studies $23,467-486$. 
Walker, D., 2009, A Review of Corporate Governance in UK banks and other Financial Industry Entities: Final Recommendations. On line document available from http://www.hmtreasury.gov.uk/walker_review_information.htm.

Weisbach, M., 1988, Outside Directors and CEO Turnover. Journal of Financial Economics 20, 431-460. 
Table I: Number of Observations per Country over Time

This table shows the number of banks available for each country-year.

\begin{tabular}{|c|c|c|c|c|c|c|c|c|c|c|}
\hline Country & 2000 & 2001 & 2002 & 2003 & 2004 & 2005 & 2006 & 2007 & 2008 & 2000-2008 \\
\hline Argentina & 0 & 0 & 0 & 1 & 1 & 2 & 2 & 2 & 2 & 10 \\
\hline Australia & 0 & 0 & 0 & 2 & 8 & 8 & 8 & 8 & 7 & 41 \\
\hline Austria & 1 & 1 & 1 & 1 & 1 & 2 & 2 & 6 & 6 & 21 \\
\hline Belgium & 3 & 4 & 4 & 4 & 3 & 3 & 3 & 3 & 3 & 30 \\
\hline Belize & 1 & 1 & 1 & 1 & 1 & 1 & 1 & 1 & 1 & 9 \\
\hline Brazil & 0 & 0 & 0 & 0 & 0 & 1 & 1 & 2 & 2 & 6 \\
\hline Canada & 0 & 0 & 0 & 5 & 5 & 6 & 8 & 9 & 9 & 42 \\
\hline Chile & 0 & 0 & 0 & 0 & 0 & 1 & 1 & 1 & 1 & 4 \\
\hline China & 0 & 0 & 0 & 0 & 0 & 0 & 0 & 3 & 3 & 6 \\
\hline Czech Republic & 0 & 0 & 0 & 0 & 0 & 0 & 0 & 1 & 1 & 2 \\
\hline Denmark & 1 & 2 & 2 & 2 & 2 & 3 & 3 & 3 & 3 & 21 \\
\hline Egypt & 0 & 0 & 0 & 0 & 0 & 0 & 0 & 1 & 1 & 2 \\
\hline Finland & 0 & 0 & 0 & 0 & 0 & 0 & 0 & 1 & 1 & 2 \\
\hline France & 4 & 5 & 5 & 4 & 4 & 5 & 5 & 5 & 5 & 42 \\
\hline Germany & 8 & 8 & 9 & 10 & 10 & 10 & 10 & 9 & 9 & 83 \\
\hline Greece & 4 & 5 & 5 & 5 & 6 & 6 & 7 & 7 & 7 & 52 \\
\hline Hong Kong & 0 & 0 & 0 & 0 & 0 & 0 & 0 & 1 & 1 & 2 \\
\hline Hungary & 0 & 0 & 0 & 0 & 0 & 0 & 0 & 1 & 1 & 2 \\
\hline India & 0 & 0 & 0 & 0 & 0 & 1 & 2 & 5 & 15 & 23 \\
\hline Italy & 10 & 12 & 12 & 14 & 16 & 14 & 12 & 13 & 13 & 116 \\
\hline Japan & 0 & 0 & 0 & 0 & 0 & 0 & 0 & 0 & 2 & 2 \\
\hline Liechtenstein & 2 & 2 & 2 & 2 & 2 & 2 & 2 & 2 & 2 & 18 \\
\hline Luxembourg & 0 & 0 & 0 & 0 & 0 & 0 & 1 & 1 & 1 & 3 \\
\hline Malaysia & 0 & 0 & 0 & 0 & 0 & 0 & 0 & 0 & 1 & 1 \\
\hline Morocco & 0 & 0 & 0 & 0 & 0 & 1 & 1 & 1 & 1 & 4 \\
\hline Netherlands & 2 & 3 & 3 & 3 & 3 & 4 & 4 & 4 & 3 & 29 \\
\hline Nigeria & 0 & 0 & 0 & 0 & 0 & 0 & 1 & 2 & 4 & 7 \\
\hline Norway & 1 & 1 & 1 & 2 & 1 & 1 & 1 & 1 & 1 & 10 \\
\hline Poland & 1 & 1 & 1 & 1 & 1 & 1 & 1 & 5 & 5 & 17 \\
\hline Portugal & 2 & 2 & 2 & 2 & 2 & 3 & 3 & 4 & 4 & 24 \\
\hline Puerto Rico & 3 & 4 & 4 & 5 & 6 & 6 & 6 & 4 & 4 & 42 \\
\hline Ireland & 2 & 2 & 2 & 2 & 2 & 2 & 2 & 2 & 2 & 18 \\
\hline Russia & 0 & 0 & 0 & 0 & 0 & 1 & 1 & 3 & 3 & 8 \\
\hline Spain & 5 & 6 & 6 & 6 & 6 & 6 & 8 & 8 & 8 & 59 \\
\hline Sweden & 4 & 5 & 5 & 5 & 5 & 5 & 5 & 5 & 5 & 44 \\
\hline Switzerland & 4 & 4 & 4 & 4 & 4 & 5 & 5 & 5 & 5 & 40 \\
\hline Taiwan & 0 & 0 & 0 & 0 & 0 & 0 & 0 & 1 & 1 & 2 \\
\hline Turkey & 0 & 0 & 0 & 0 & 0 & 0 & 0 & 5 & 5 & 10 \\
\hline United Arab Emirates & 0 & 0 & 0 & 0 & 0 & 0 & 1 & 0 & 0 & 1 \\
\hline United Kingdom & 11 & 11 & 11 & 13 & 14 & 13 & 15 & 14 & 14 & 116 \\
\hline United States & 108 & 123 & 126 & 341 & 455 & 492 & 500 & 483 & 478 & 3106 \\
\hline All countries & 177 & 202 & 206 & 435 & 558 & 605 & 622 & 632 & 640 & 4077 \\
\hline
\end{tabular}




\section{Table II: Summary Statistics}

The sample consists of an unbalanced panel of 4,205 bank level observations from 718 banks for the period 2000-2008. Director data are from the BoardEx database. We obtain additional financial information from Worldscope and Bankscope, and country information from Djankov et al. (2008), La Porta et al. (1998), Euromonitor, and the World Bank Database. Independence is the ratio of independent outside directors over board size. Board size is the number of directors on the board. Banking Experience is the ratio of outside directors with prior managerial or top-executive experience in banking over all outside directors. Busyness is the average number of commercial and non-commercial outside director appointments of all outside directors. Assets is the book value of total assets (in billions of USD). Sales growth is the annual change in sales over the previous year's sales volume. Market-to-book is market value of equity over book common equity. ROA (return on assets) is net income over assets. Leverage is assets over common equity. Block ownership is a dummy that is equal to one if an owner holds a block of at least $10 \%$ of the shares. The variable Antidirector is obtained by multiplying the anti-director rights index constructed by Djankov et al. (2008) with the rule of law index reported by La Porta et al. (1998). GDP per capita (PPP adjusted, in thousands of 2005 international USD) is sourced from the World Bank's World Development Indicators, and market capitalization over GDP (a measure of financial development) is provided by Euromonitor. Removal of directors by courts is a dummy variable that equals 1 if courts are allowed to remove bank directors; this variable is taken from the revised World Bank database on bank regulation and supervisory practices developed by Caprio, Levine and Barth (2008). One-tier board is a dummy variable that equals 1 if boards are required to have a unitary board structure; this variable was hand-collected from various sources.

\begin{tabular}{l|rrrrr}
\hline Variable & mean & st. dev. & min & max & count \\
\hline & \multicolumn{5}{|c}{ Board Characteristics } \\
\hline Independence & 0.622 & 0.239 & 0.000 & 0.955 & 4076 \\
Banking Experience & 0.232 & 0.198 & 0.000 & 1.000 & 4076 \\
Board Size & 12.235 & 4.804 & 4.000 & 35.000 & 4076 \\
Busyness & 2.998 & 1.554 & 1.000 & 15.800 & 4074 \\
\hline & 75.698 & 266.783 & 0.020 & 3765.035 & 4064 \\
\hline Assets & 4.829 & 15.756 & 0.003 & 173.617 & 4055 \\
Sales & 1.823 & 0.928 & 0.091 & 14.303 & 4035 \\
Market-to-Book & 0.008 & 0.017 & -0.488 & 0.301 & 4062 \\
ROA & 13.980 & 9.245 & 0.956 & 165.227 & 4059 \\
Leverage & 0.335 & 0.472 & 0.000 & 1.000 & 3799 \\
Block ownership & \multicolumn{5}{|c}{ Country Characteristics } \\
\hline & 17.946 & 2.961 & 3.583 & 25.714 & 4038 \\
\hline Antidirector & 39.990 & 8.949 & 1.795 & 122.100 & 4076 \\
GDP per capita (2006) & 1.369 & 0.354 & 0.000 & 4.714 & 4076 \\
Market cap over GDP (2006) & 0.855 & 0.352 & 0.000 & 1.000 & 4075 \\
Removal of directors by courts & 0.877 & 0.328 & 0.000 & 1.000 & 4076 \\
One-tier board & \multicolumn{5}{c}{ Characteristics } \\
\hline
\end{tabular}


Table III: Summary Statistics of Bank Board Characteristics in 2006

This table shows summary statistics of four bank board characteristics across countries in 2006. Independence is the ratio of independent directors over board size. Banking Experience is the ratio of outside directors with prior managerial or top-executive experience in banking over all outside directors. Board size is the number of directors on the board. Busyness is the average number of commercial and non-commercial outside director appointments of all outside directors.

\begin{tabular}{|c|c|c|c|c|c|c|c|c|c|c|c|c|c|c|c|c|c|c|c|c|}
\hline \multirow[t]{2}{*}{ Country } & \multicolumn{5}{|c|}{ Independence } & \multicolumn{5}{|c|}{ Banking Experience } & \multicolumn{5}{|c|}{ Board Size } & \multicolumn{5}{|c|}{ Busyness } \\
\hline & mean & s.d. & $\min$ & $\max$ & count & mean & s.d. & $\min$ & $\max$ & count & mean & s.d. & $\min$ & $\max$ & count & mean & s.d. & $\min$ & $\max$ & count \\
\hline Argentina & 0.297 & 0.016 & 0.286 & 0.308 & 2 & 0.414 & 0.020 & 0.400 & 0.429 & 2 & 10.000 & 4.243 & 7 & 13 & 2 & 5.143 & 2.626 & 3.286 & 7.000 & 2 \\
\hline Australia & 0.760 & 0.110 & 0.625 & 0.900 & 8 & 0.186 & 0.165 & 0.000 & 0.500 & 8 & 9.250 & 1.832 & 7 & 13 & 8 & 4.100 & 0.559 & 3.167 & 5.000 & 8 \\
\hline Austria & 0.479 & 0.029 & 0.458 & 0.500 & 2 & 0.750 & 0.354 & 0.500 & 1.000 & 2 & 18.000 & 8.485 & 12 & 24 & 2 & 4.444 & 2.200 & 2.889 & 6.000 & 2 \\
\hline Belgium & 0.192 & 0.213 & 0.000 & 0.421 & 3 & 0.215 & 0.238 & 0.000 & 0.471 & 3 & 18.000 & 8.544 & 9 & 26 & 3 & 4.896 & 2.795 & 1.800 & 7.235 & 3 \\
\hline Belize & 0.000 & 0 & 0.000 & 0.000 & 1 & 0.200 & 0 & 0 & 0.200 & 1 & 6.000 & 0 & 6 & 6 & 1 & 4.400 & 0 & 4 & 4.400 & 1 \\
\hline Brazil & 0.063 & 0 & 0.063 & 0.063 & 1 & 0.786 & 0 & 1 & 0.786 & 1 & 16.000 & 0 & 16 & 16 & 1 & 2.000 & 0 & 2 & 2.000 & 1 \\
\hline Canada & 0.745 & 0.230 & 0.200 & 0.889 & 8 & 0.110 & 0.137 & 0.000 & 0.375 & 8 & 15.375 & 3.114 & 9 & 19 & 8 & 4.135 & 0.584 & 3.250 & 5.133 & 8 \\
\hline Chile & 0.133 & 0 & 0.133 & 0.133 & 1 & 0.692 & 0 & 1 & 0.692 & 1 & 15.000 & 0 & 15 & 15 & 1 & 2.615 & 0 & 3 & 2.615 & 1 \\
\hline Denmark & 0.175 & 0.304 & 0.000 & 0.526 & 3 & 0.389 & 0.096 & 0.333 & 0.500 & 3 & 15.667 & 3.055 & 13 & 19 & 3 & 3.367 & 1.082 & 2.167 & 4.267 & 3 \\
\hline France & 0.122 & 0.095 & 0.000 & 0.250 & 5 & 0.563 & 0.108 & 0.385 & 0.650 & 5 & 21.000 & 5.568 & 14 & 26 & 5 & 8.473 & 3.664 & 4.571 & 13.700 & 5 \\
\hline Germany & 0.383 & 0.123 & 0.160 & 0.545 & 10 & 0.559 & 0.234 & 0.300 & 1.000 & 10 & 21.300 & 7.319 & 8 & 29 & 10 & 4.833 & 1.048 & 3.250 & 6.450 & 10 \\
\hline Greece & 0.211 & 0.172 & 0.000 & 0.563 & 7 & 0.396 & 0.245 & 0.083 & 0.778 & 7 & 14.286 & 2.215 & 11 & 17 & 7 & 2.335 & 0.853 & 1.250 & 3.333 & 7 \\
\hline India & 0.622 & 0.118 & 0.538 & 0.706 & 2 & 0.292 & 0.295 & 0.083 & 0.500 & 2 & 15.000 & 2.828 & 13 & 17 & 2 & 8.758 & 4.467 & 5.600 & 11.917 & 2 \\
\hline Ireland & 0.655 & 0.017 & 0.643 & 0.667 & 2 & 0.125 & 0.059 & 0.083 & 0.167 & 2 & 14.500 & 0.707 & 14 & 15 & 2 & 4.875 & 2.062 & 3.417 & 6.333 & 2 \\
\hline Italy & 0.395 & 0.339 & 0.000 & 0.955 & 12 & 0.401 & 0.130 & 0.200 & 0.722 & 12 & 17.583 & 4.337 & 10 & 24 & 12 & 5.605 & 3.379 & 1.444 & 13.615 & 12 \\
\hline Liechtenstein & 0.292 & 0.412 & 0.000 & 0.583 & 2 & 0.286 & 0.000 & 0.286 & 0.286 & 2 & 11.000 & 1.414 & 10 & 12 & 2 & 3.286 & 0.606 & 2.857 & 3.714 & 2 \\
\hline Luxembourg & 0.261 & 0 & 0.261 & 0.261 & 1 & 0.526 & 0 & 1 & 0.526 & 1 & 23.000 & 0 & 23 & 23 & 1 & 8.632 & 0 & 9 & 8.632 & 1 \\
\hline Morocco & 0.000 & 0 & 0.000 & 0.000 & 1 & 0.500 & 0 & 1 & 0.500 & 1 & 13.000 & 0 & 13 & 13 & 1 & 4.000 & 0 & 4 & 4.000 & 1 \\
\hline Netherlands & 0.519 & 0.181 & 0.250 & 0.643 & 4 & 0.263 & 0.090 & 0.167 & 0.385 & 4 & 14.000 & 4.320 & 10 & 20 & 4 & 6.557 & 1.564 & 5.125 & 8.667 & 4 \\
\hline Nigeria & 0.000 & 0 & 0.000 & 0.000 & 1 & 0.167 & 0 & 0 & 0.167 & 1 & 11.000 & 0 & 11 & 11 & 1 & 2.333 & 0 & 2 & 2.333 & 1 \\
\hline Norway & 0.240 & 0 & 0.240 & 0.240 & 1 & 0.250 & 0 & 0 & 0.250 & 1 & 25.000 & 0 & 25 & 25 & 1 & 3.125 & 0 & 3 & 3.125 & 1 \\
\hline Poland & 0.000 & 0 & 0.000 & 0.000 & 1 & 0.444 & 0 & 0 & 0.444 & 1 & 17.000 & 0 & 17 & 17 & 1 & 4.333 & 0 & 4 & 4.333 & 1 \\
\hline Portugal & 0.258 & 0.108 & 0.161 & 0.375 & 3 & 0.579 & 0.084 & 0.500 & 0.667 & 3 & 25.333 & 5.132 & 21 & 31 & 3 & 8.175 & 3.246 & 4.429 & 10.167 & 3 \\
\hline Puerto Rico & 0.711 & 0.094 & 0.571 & 0.800 & 6 & 0.189 & 0.221 & 0.000 & 0.600 & 6 & 8.333 & 1.211 & 7 & 10 & 6 & 3.006 & 0.969 & 2.000 & 4.750 & 6 \\
\hline Russia & 0.000 & 0 & 0.000 & 0.000 & 1 & 0.429 & 0 & 0 & 0.429 & 1 & 34.000 & 0 & 34 & 34 & 1 & 1.929 & 0 & 2 & 1.929 & 1 \\
\hline Spain & 0.401 & 0.219 & 0.000 & 0.667 & 8 & 0.482 & 0.220 & 0.222 & 0.800 & 8 & 13.625 & 3.249 & 10 & 19 & 8 & 3.121 & 1.175 & 2.100 & 5.714 & 8 \\
\hline Sweden & 0.442 & 0.078 & 0.333 & 0.533 & 5 & 0.275 & 0.102 & 0.111 & 0.357 & 5 & 13.200 & 2.168 & 10 & 15 & 5 & 4.975 & 0.936 & 3.900 & 6.000 & 5 \\
\hline Switzerland & 0.105 & 0.143 & 0.000 & 0.273 & 5 & 0.261 & 0.102 & 0.100 & 0.375 & 5 & 17.600 & 5.595 & 10 & 24 & 5 & 3.404 & 1.912 & 1.818 & 6.077 & 5 \\
\hline UAE & 0.000 & 0 & 0.000 & 0.000 & 1 & 0.000 & 0 & 0 & 0.000 & 1 & 8.000 & 0 & 8 & 8 & 1 & 1.143 & 0 & 1 & 1.143 & 1 \\
\hline United Kingdom & 0.449 & 0.183 & 0.000 & 0.643 & 15 & 0.364 & 0.130 & 0.188 & 0.667 & 15 & 12.400 & 4.067 & 6 & 19 & 15 & 5.032 & 1.142 & 3.400 & 7.625 & 15 \\
\hline United States & 0.738 & 0.129 & 0.000 & 0.938 & 500 & 0.178 & 0.160 & 0.000 & 0.750 & 500 & 10.742 & 3.326 & 4 & 23 & 500 & 2.478 & 0.712 & 1.000 & 6.000 & 500 \\
\hline
\end{tabular}


Table IV: Regressions of Board Characteristics on Bank Characteristics and Country Dummies in 2006

This table shows ordinary least squares regressions of two board characteristics on bank characteristics and country dummies in 2006. The dependent variable in columns (a)-(c) is the logistic transformation of board independence. The dependent variable in columns (d)-(f) is the logistic transformation of board experience. See Table II for the definition of variables. Robust t-statistics (clustered by country) are in brackets. Asterisks indicate significance at $0.01(* * *), 0.05(* *)$, and $0.10(*)$ levels.

\begin{tabular}{|c|c|c|c|c|c|c|}
\hline \multirow[t]{3}{*}{ Independent Variable } & \multicolumn{6}{|c|}{ Dependent Variable } \\
\hline & \multicolumn{3}{|c|}{ Independence } & \multicolumn{3}{|c|}{ Banking Experience } \\
\hline & (a) & (b) & (c) & (d) & (e) & (f) \\
\hline Log(Assets) & $\begin{array}{l}-0.322 \\
{[-0.451]}\end{array}$ & & $\begin{array}{l}0.229 \\
{[0.659]}\end{array}$ & $\begin{array}{l}-0.435 \\
{[-1.132]}\end{array}$ & & $\begin{array}{l}-0.609 * * \\
{[-2.259]}\end{array}$ \\
\hline Log(Sales) & $\begin{array}{l}0.045 \\
{[0.070]}\end{array}$ & & $\begin{array}{l}-0.170 \\
{[-0.417]}\end{array}$ & $\begin{array}{l}0.935^{* *} \\
{[2.379]}\end{array}$ & & $\begin{array}{l}1.020 * * * \\
{[2.914]}\end{array}$ \\
\hline Log(Market-to-Book) & $\begin{array}{l}-0.342 \\
{[-0.546]}\end{array}$ & & $\begin{array}{l}0.003 \\
{[0.013]}\end{array}$ & $\begin{array}{l}0.460 \\
{[0.791]}\end{array}$ & & $\begin{array}{l}0.130 \\
{[0.384]}\end{array}$ \\
\hline ROA & $\begin{array}{l}16.088^{*} \\
{[1.814]}\end{array}$ & & $\begin{array}{l}12.939 * * \\
{[2.161]}\end{array}$ & $\begin{array}{l}0.155 \\
{[0.039]}\end{array}$ & & $\begin{array}{l}2.421 \\
{[0.976]}\end{array}$ \\
\hline $\log ($ Leverage $)$ & $\begin{array}{l}0.162 \\
{[0.407]}\end{array}$ & & $\begin{array}{l}0.377 \\
{[1.613]}\end{array}$ & $\begin{array}{l}-0.069 \\
{[-0.208]}\end{array}$ & & $\begin{array}{l}-0.050 \\
{[-0.158]}\end{array}$ \\
\hline Observations & 609 & 609 & 609 & 609 & 609 & 609 \\
\hline Number of Countries & 31 & 31 & 31 & 31 & 31 & 31 \\
\hline Adjusted $\mathrm{R}^{2}$ & 0.104 & 0.538 & 0.570 & 0.068 & 0.027 & 0.051 \\
\hline Country dummies & No & Yes & Yes & No & Yes & Yes \\
\hline
\end{tabular}


Table V: Regressions of Board Characteristics on Bank Characteristics and Country Dummies in 2006, with Ownership Controls

This table shows ordinary least squares regressions of two board characteristics on bank characteristics and country dummies in 2006. The dependent variable in columns (a)-(c) is the logistic transformation of board independence. The dependent variable in columns (d)-(f) is the logistic transformation of board experience. See Table II for the definition of variables. Robust t-statistics (clustered by country) are in brackets. Asterisks indicate significance at $0.01(* * *), 0.05(* *)$, and $0.10(*)$ levels.

\begin{tabular}{|c|c|c|c|c|c|c|}
\hline \multirow[t]{3}{*}{ Independent Variable } & \multicolumn{6}{|c|}{ Dependent Variable } \\
\hline & \multicolumn{3}{|c|}{ Independence } & \multicolumn{3}{|c|}{ Banking Experience } \\
\hline & (a) & (b) & (c) & (d) & (e) & (f) \\
\hline Log(Assets) & $\begin{array}{l}-1.556 \\
{[-1.513]}\end{array}$ & & $\begin{array}{l}-0.638 \\
{[-1.147]}\end{array}$ & $\begin{array}{l}-0.362 \\
{[-0.671]}\end{array}$ & & $\begin{array}{l}-0.830 * * \\
{[-2.459]}\end{array}$ \\
\hline $\log ($ Sales $)$ & $\begin{array}{l}1.338 \\
{[1.361]}\end{array}$ & & $\begin{array}{l}0.707 \\
{[1.121]}\end{array}$ & $\begin{array}{l}0.903 \\
{[1.650]}\end{array}$ & & $\begin{array}{l}1.215^{* * *} * \\
{[3.618]}\end{array}$ \\
\hline Log(Market-to-Book) & $\begin{array}{l}-0.198 \\
{[-0.332]}\end{array}$ & & $\begin{array}{l}0.072 \\
{[0.267]}\end{array}$ & $\begin{array}{l}0.740 \\
{[0.968]}\end{array}$ & & $\begin{array}{l}0.315 \\
{[0.604]}\end{array}$ \\
\hline ROA & $\begin{array}{l}-29.313 \\
{[-1.012]}\end{array}$ & & $\begin{array}{l}-17.563 \\
{[-1.045]}\end{array}$ & $\begin{array}{l}-21.811 \\
{[-1.426]}\end{array}$ & & $\begin{array}{l}-18.548 \\
{[-1.398]}\end{array}$ \\
\hline Log(Leverage $)$ & $\begin{array}{l}-0.212 \\
{[-0.476]}\end{array}$ & & $\begin{array}{l}0.059 \\
{[0.243]}\end{array}$ & $\begin{array}{l}0.050 \\
{[0.090]}\end{array}$ & & $\begin{array}{l}-0.089 \\
{[-0.145]}\end{array}$ \\
\hline Block holder & $\begin{array}{l}-0.712 * * \\
{[-2.123]} \\
\end{array}$ & & $\begin{array}{l}-0.163 \\
{[-1.002]}\end{array}$ & $\begin{array}{l}-0.195 \\
{[-0.252]}\end{array}$ & & $\begin{array}{l}-0.748 * \\
{[-1.915]}\end{array}$ \\
\hline Observations & 572 & 572 & 572 & 572 & 572 & 572 \\
\hline Number of Countries & 31 & 31 & 31 & 31 & 31 & 31 \\
\hline $\begin{array}{l}\text { Adjusted } \mathrm{R}^{2} \\
\text { Country dummies }\end{array}$ & $\begin{array}{l}0.125 \\
\text { No }\end{array}$ & $\begin{array}{l}0.566 \\
\text { Yes }\end{array}$ & $\begin{array}{l}0.571 \\
\text { Yes }\end{array}$ & $\begin{array}{l}0.074 \\
\text { No }\end{array}$ & $\begin{array}{l}0.056 \\
\text { Yes }\end{array}$ & $\begin{array}{l}0.079 \\
\text { Yes }\end{array}$ \\
\hline
\end{tabular}


Table VI: Bank Board Independence Gaps in 2006

This table shows the average difference in board independence between non-US banks and matched US banks. A negative gap means that the country has a lower level of board independence than what is observed in similar US banks (by construction, the US has an independence gap of zero). In columns (a) and (b) banks are matched on five characteristics (assets, sales, market-to-book, ROA, and leverage) using the nearest neighbor propensity matching procedure. In columns (c) and (d) country averages are compared with the US average, without matching on characteristics. Columns (b) and (d) use banks' selfreported independence classifications, while columns (a) and (c) use our independence variable, which is corrected for internally appointed directors, client-directors, and employee representatives.

\begin{tabular}{|c|c|c|c|c|c|}
\hline \multirow[b]{3}{*}{ Country } & \multicolumn{4}{|c|}{ Independence gap } & \multirow[b]{3}{*}{ count } \\
\hline & \multicolumn{2}{|c|}{ Matched sample } & \multicolumn{2}{|c|}{ No matching } & \\
\hline & Corrected & Self-reported & Corrected & Self-reported & \\
\hline & (a) & (b) & (c) & (d) & \\
\hline Argentina & -0.429 & -0.465 & -0.441 & -0.464 & 2 \\
\hline Austria & 0.017 & -0.032 & 0.023 & 0.053 & 8 \\
\hline Australia & -0.096 & -0.260 & -0.259 & -0.136 & 2 \\
\hline Belgium & -0.352 & -0.666 & -0.546 & -0.569 & 3 \\
\hline Brazil & -0.667 & -0.667 & -0.738 & -0.761 & 1 \\
\hline Belize & -0.820 & -0.820 & -0.675 & -0.699 & 1 \\
\hline Canada & 0.210 & 0.037 & 0.007 & 0.036 & 8 \\
\hline Switzerland & -0.415 & -0.603 & -0.633 & -0.588 & 5 \\
\hline Chile & -0.700 & -0.700 & -0.605 & -0.628 & 1 \\
\hline Germany & -0.285 & -0.804 & -0.355 & -0.743 & 10 \\
\hline Denmark & -0.237 & -0.394 & -0.562 & -0.498 & 3 \\
\hline Spain & -0.383 & -0.356 & -0.337 & -0.274 & 8 \\
\hline France & -0.668 & -0.531 & -0.616 & -0.502 & 5 \\
\hline United Kingdom & -0.164 & -0.280 & -0.289 & -0.286 & 15 \\
\hline Greece & -0.458 & -0.631 & -0.527 & -0.542 & 7 \\
\hline India & -0.245 & -0.245 & -0.116 & -0.139 & 2 \\
\hline Ireland & -0.051 & -0.176 & -0.083 & -0.106 & 2 \\
\hline Italy & -0.303 & -0.326 & -0.343 & -0.325 & 12 \\
\hline Liechtenstein & -0.337 & -0.337 & -0.446 & -0.469 & 2 \\
\hline Luxembourg & -0.364 & -0.614 & -0.477 & -0.500 & 1 \\
\hline Morocco & -0.867 & -0.867 & -0.738 & -0.761 & 1 \\
\hline Nigeria & -0.667 & -0.667 & -0.738 & -0.761 & 1 \\
\hline Netherlands & -0.023 & -0.140 & -0.219 & -0.096 & 4 \\
\hline Norway & -0.546 & -0.546 & -0.498 & -0.521 & 1 \\
\hline Poland & -0.667 & -0.667 & -0.738 & -0.761 & 1 \\
\hline Puerto Rico & 0.015 & -0.017 & -0.027 & -0.033 & 6 \\
\hline Portugal & -0.524 & -0.533 & -0.480 & -0.389 & 3 \\
\hline Russia & -0.786 & -0.786 & -0.738 & -0.761 & 1 \\
\hline Sweden & -0.313 & -0.305 & -0.295 & -0.211 & 5 \\
\hline
\end{tabular}


Table VII: Bank Board Experience Gaps in 2006

This table shows the average difference in board experience between non-US banks and matched US banks. A negative gap means that the country has a lower level of board experience than what is observed in similar US banks (by construction, the US has an experience gap of zero). In column I banks are matched on five characteristics (assets, sales, market-to-book, ROA, and leverage) using the nearest neighbor propensity matching procedure. In column (b) country averages are compared with the US average, without matching on characteristics.

\begin{tabular}{|c|c|c|c|}
\hline \multirow[b]{2}{*}{ Country } & \multicolumn{3}{|c|}{ Experience gap } \\
\hline & Matched sample & No matching & count \\
\hline & (a) & (b) & \\
\hline Argentina & 0.188 & 0.236 & 2 \\
\hline Austria & -0.034 & 0.008 & 8 \\
\hline Australia & 0.620 & 0.572 & 2 \\
\hline Belgium & 0.075 & 0.037 & 3 \\
\hline Brazil & -0.300 & 0.022 & 1 \\
\hline Belize & 0.661 & 0.608 & 1 \\
\hline Canada & -0.081 & -0.067 & 8 \\
\hline Switzerland & 0.018 & 0.083 & 5 \\
\hline Chile & 0.601 & 0.514 & 1 \\
\hline Germany & 0.373 & 0.381 & 10 \\
\hline Denmark & 0.292 & 0.211 & 3 \\
\hline Spain & 0.295 & 0.304 & 8 \\
\hline France & 0.379 & 0.386 & 5 \\
\hline United Kingdom & 0.138 & 0.186 & 15 \\
\hline Greece & 0.194 & 0.218 & 7 \\
\hline India & 0.059 & 0.114 & 2 \\
\hline Ireland & 0.015 & -0.053 & 2 \\
\hline Italy & 0.222 & 0.224 & 12 \\
\hline Liechtenstein & -0.046 & 0.108 & 2 \\
\hline Luxembourg & 0.383 & 0.348 & 1 \\
\hline Morocco & 0.500 & 0.322 & 1 \\
\hline Nigeria & -0.083 & -0.011 & 1 \\
\hline Netherlands & 0.030 & 0.085 & 4 \\
\hline Norway & 0.173 & 0.072 & 1 \\
\hline Poland & 0.244 & 0.267 & 1 \\
\hline Puerto Rico & -0.064 & 0.011 & 6 \\
\hline Portugal & 0.432 & 0.402 & 3 \\
\hline Russia & 0.352 & 0.251 & 1 \\
\hline Sweden & 0.128 & 0.097 & 5 \\
\hline
\end{tabular}


Table VIII: Regressions of Board Characteristics on Bank Characteristics and Country Characteristics

This table shows ordinary least squares regressions of two board characteristics on bank characteristics and country characteristics in 2006 and for the 2000-2008 period. The dependent variable in columns (a)-(b) and (e)-(f) is the logistic transformation of board independence. The dependent variable in columns (c)-(d) and (g)-(h) is the logistic transformation of board experience. See Table II for the definition of variables. Robust t-statistics (clustered by country) are in brackets. Asterisks indicate significance at $0.01(* * *), 0.05(* *)$, and $0.10(*)$ levels.

\begin{tabular}{|c|c|c|c|c|c|c|c|c|}
\hline \multirow[t]{3}{*}{ Independent Variable } & \multicolumn{8}{|c|}{ Dependent Variable } \\
\hline & \multicolumn{2}{|c|}{ Independence } & \multicolumn{2}{|c|}{ Banking Experience } & \multicolumn{2}{|c|}{ Independence } & \multicolumn{2}{|c|}{ Banking Experience } \\
\hline & (a) & (b) & (c) & (d) & (e) & (f) & (g) & (h) \\
\hline Log(Assets) & $\begin{array}{l}0.213 \\
{[0.637]}\end{array}$ & $\begin{array}{l}-0.327 \\
{[-0.593]}\end{array}$ & $\begin{array}{l}-0.916 * * * \\
{[-3.224]}\end{array}$ & $\begin{array}{l}-0.394 \\
{[-1.149]}\end{array}$ & $\begin{array}{l}-0.762 \\
{[-1.280]}\end{array}$ & $\begin{array}{l}-0.902 \\
{[-1.359]}\end{array}$ & $\begin{array}{l}-1.190 * * * \\
{[-2.943]}\end{array}$ & $\begin{array}{l}-0.130 \\
{[-0.222]}\end{array}$ \\
\hline $\log ($ Sales $)$ & $\begin{array}{l}-0.198 \\
{[-0.562]}\end{array}$ & $\begin{array}{l}0.331 \\
{[0.579]}\end{array}$ & $\begin{array}{l}1.261 * * * \\
{[3.716]}\end{array}$ & $\begin{array}{l}0.704 * * \\
{[2.325]}\end{array}$ & $\begin{array}{l}0.800 \\
{[1.281]}\end{array}$ & $\begin{array}{l}0.893 \\
{[1.300]}\end{array}$ & $\begin{array}{l}1.537 * * * \\
{[4.303]}\end{array}$ & $\begin{array}{l}0.442 \\
{[0.859]}\end{array}$ \\
\hline Log(Market-to-Book) & $\begin{array}{l}0.179 \\
{[0.400]}\end{array}$ & $\begin{array}{l}0.130 \\
{[0.416]}\end{array}$ & $\begin{array}{l}0.396 \\
{[0.836]}\end{array}$ & $\begin{array}{l}0.049 \\
{[0.113]}\end{array}$ & $\begin{array}{l}0.302 \\
{[0.603]}\end{array}$ & $\begin{array}{l}0.262 \\
{[0.789]}\end{array}$ & $\begin{array}{l}0.459 \\
{[0.878]}\end{array}$ & $\begin{array}{l}0.111 \\
{[0.230]}\end{array}$ \\
\hline ROA & $\begin{array}{l}12.472 * \\
{[1.947]}\end{array}$ & $\begin{array}{l}4.109 \\
{[0.520]}\end{array}$ & $\begin{array}{l}2.708^{* *} \\
{[2.072]}\end{array}$ & $\begin{array}{l}-0.832 \\
{[-0.194]}\end{array}$ & $\begin{array}{l}-31.163 \\
{[-1.270]}\end{array}$ & $\begin{array}{l}-10.101 \\
{[-1.207]}\end{array}$ & $\begin{array}{l}-22.494 \\
{[-1.615]}\end{array}$ & $\begin{array}{l}-6.669 \\
{[-0.814]}\end{array}$ \\
\hline $\log ($ Leverage $)$ & $\begin{array}{l}0.367 \\
{[1.537]}\end{array}$ & $\begin{array}{l}0.384 \\
{[1.119]}\end{array}$ & $\begin{array}{l}-0.459 \\
{[-1.085]}\end{array}$ & $\begin{array}{l}-0.497 \\
{[-1.481]}\end{array}$ & $\begin{array}{l}0.020 \\
{[0.073]}\end{array}$ & $\begin{array}{l}0.274 \\
{[0.670]}\end{array}$ & $\begin{array}{l}-0.352 \\
{[-0.584]}\end{array}$ & $\begin{array}{l}-0.492 \\
{[-1.162]}\end{array}$ \\
\hline Legal Origin - French & $\begin{array}{l}-0.784 \\
{[-0.867]}\end{array}$ & $\begin{array}{l}-1.202 \\
{[-1.465]}\end{array}$ & $\begin{array}{l}2.018 * * * \\
{[2.840]}\end{array}$ & $\begin{array}{l}2.007 * * * \\
{[3.313]}\end{array}$ & $\begin{array}{l}-0.575 \\
{[-0.656]}\end{array}$ & $\begin{array}{l}-0.824 \\
{[-0.987]}\end{array}$ & $\begin{array}{l}2.323 * * * \\
{[3.348]}\end{array}$ & $\begin{array}{l}1.911 * * * \\
{[3.038]}\end{array}$ \\
\hline Legal Origin - German & $\begin{array}{l}-2.055 * * \\
{[-2.359]}\end{array}$ & $\begin{array}{l}-2.509 * * * \\
{[-2.810]}\end{array}$ & $\begin{array}{l}2.386^{* *} \\
{[2.322]}\end{array}$ & $\begin{array}{l}1.716^{* *} \\
{[2.256]}\end{array}$ & $\begin{array}{l}-1.625^{*} \\
{[-1.834]}\end{array}$ & $\begin{array}{l}-2.251^{* *} \\
{[-2.554]}\end{array}$ & $\begin{array}{l}2.827 * * \\
{[2.752]}\end{array}$ & $\begin{array}{l}1.704 * * \\
{[2.254]}\end{array}$ \\
\hline Antidirector & $\begin{array}{l}0.002 \\
{[0.025]}\end{array}$ & $\begin{array}{l}-0.013 \\
{[-0.166]}\end{array}$ & $\begin{array}{l}0.046 \\
{[0.459]}\end{array}$ & $\begin{array}{l}0.062 \\
{[0.812]}\end{array}$ & $\begin{array}{l}0.020 \\
{[0.248]}\end{array}$ & $\begin{array}{l}0.009 \\
{[0.105]}\end{array}$ & $\begin{array}{l}0.030 \\
{[0.261]}\end{array}$ & $\begin{array}{l}0.057 \\
{[0.669]}\end{array}$ \\
\hline GDP per capita (2006) & $\begin{array}{l}0.165^{* * * *} \\
{[3.735]}\end{array}$ & $\begin{array}{l}0.154 * * * \\
{[3.776]}\end{array}$ & $\begin{array}{l}-0.016 \\
{[-0.467]}\end{array}$ & $\begin{array}{l}-0.007 \\
{[-0.222]}\end{array}$ & $\begin{array}{l}0.169 * * * \\
{[3.828]}\end{array}$ & $\begin{array}{l}0.151 * * * \\
{[3.843]}\end{array}$ & $\begin{array}{l}-0.023 \\
{[-0.665]}\end{array}$ & $\begin{array}{l}-0.012 \\
{[-0.380]}\end{array}$ \\
\hline Market cap over GDP (2006) & $\begin{array}{l}-1.417 * \\
{[-1.776]}\end{array}$ & $\begin{array}{l}-0.761 \\
{[-0.817]}\end{array}$ & $\begin{array}{l}-0.808 * \\
{[-1.907]}\end{array}$ & $\begin{array}{l}-0.978 * * * \\
{[-3.146]}\end{array}$ & $\begin{array}{l}-1.430 * \\
{[-1.821]}\end{array}$ & $\begin{array}{l}-0.789 \\
{[-0.826]}\end{array}$ & $\begin{array}{l}-0.758 * \\
{[-1.811]}\end{array}$ & $\begin{array}{l}-0.973 * * * \\
{[-3.010]}\end{array}$ \\
\hline Removal of directors by courts & $\begin{array}{l}-1.451 * \\
{[-1.925]}\end{array}$ & $\begin{array}{l}-1.557 * * \\
{[-2.150]}\end{array}$ & $\begin{array}{l}0.643 \\
{[0.866]}\end{array}$ & $\begin{array}{l}0.663 \\
{[1.269]}\end{array}$ & $\begin{array}{l}-1.442 * \\
{[-1.921]}\end{array}$ & $\begin{array}{l}-1.388 * \\
{[-1.958]}\end{array}$ & $\begin{array}{l}0.629 \\
{[0.837]}\end{array}$ & $\begin{array}{l}0.648 \\
{[1.209]}\end{array}$ \\
\hline One-tier board & $\begin{array}{l}3.108 * * * \\
{[3.171]}\end{array}$ & $\begin{array}{l}2.217 * \\
{[2.055]}\end{array}$ & $\begin{array}{l}-1.096 \\
{[-1.043]}\end{array}$ & $\begin{array}{l}-1.324 * \\
{[-1.725]}\end{array}$ & $\begin{array}{l}3.111 * * * \\
{[3.107]}\end{array}$ & $\begin{array}{l}2.338^{* *} \\
{[2.144]}\end{array}$ & $\begin{array}{l}-0.805 \\
{[-0.676]}\end{array}$ & $\begin{array}{l}-1.329 \\
{[-1.597]}\end{array}$ \\
\hline Block holder & & & & & $\begin{array}{l}-0.143 \\
{[-0.692]} \\
\end{array}$ & $\begin{array}{l}-0.124 \\
{[-0.613]} \\
\end{array}$ & $\begin{array}{l}-0.621 \\
{[-1.238]} \\
\end{array}$ & $\begin{array}{l}-0.063 \\
{[-0.236]} \\
\end{array}$ \\
\hline Observations & 609 & 3,701 & 609 & 3,701 & 572 & 3,476 & 572 & 3,476 \\
\hline Sample & 2006 & $2000-08$ & 2006 & $2000-08$ & 2006 & $2000-08$ & 2006 & $2000-08$ \\
\hline Number of Countries & 31 & 31 & 31 & 31 & 31 & 31 & 31 & 31 \\
\hline Adjusted $\mathrm{R}^{2}$ & 0.424 & 0.384 & 0.094 & 0.099 & 0.423 & 0.398 & 0.096 & 0.099 \\
\hline Year dummies & No & Yes & No & Yes & No & Yes & No & Yes \\
\hline
\end{tabular}


Table IX: Bank Fixed Effects Regressions of Board Characteristics on Bank

\section{Characteristics}

The sample consists of panel data of banks between 2000 and 2008. The dependent variable in columns (a) and (c) is the logistic transformation of board independence. The dependent variable in columns (b) and (d) is the logistic transformation of board experience. See Table II for the definition of variables. Robust t-statistics (clustered by country) are in brackets. Asterisks indicate significance at $0.01(* * *), 0.05(* *)$, and $0.10(*)$ levels. Reported $\mathrm{R}^{2}$ 's include the effect of bank dummies.

\begin{tabular}{l|l|l||l|l}
\hline Independent Variable & \multicolumn{4}{|c}{ Dependent Variable } \\
\hline & Independence & $\begin{array}{l}\text { Banking } \\
\text { Experience }\end{array}$ & Independence & $\begin{array}{l}\text { Banking } \\
\text { Experience }\end{array}$ \\
\cline { 2 - 5 } & $(\mathbf{a})$ & $\mathbf{( b )}$ & $(\mathbf{c})$ & $\mathbf{( d )}$ \\
\hline $\log ($ Assets) & -0.035 & $0.764^{* * *}$ & -0.027 & $0.904^{* * * *}$ \\
$\log ($ Sales) & {$[-0.262]$} & {$[7.753]$} & {$[-0.190]$} & {$[6.726]$} \\
& 0.227 & 0.042 & 0.240 & 0.135 \\
$\log ($ Market-to-Book) & {$[1.158]$} & {$[0.385]$} & {$[1.070]$} & {$[0.998]$} \\
& -0.088 & $-0.365^{* * *}$ & -0.097 & $-0.301^{*}$ \\
ROA & {$[-1.209]$} & {$[-2.745]$} & {$[-1.183]$} & {$[-1.805]$} \\
& -0.133 & -0.529 & -0.290 & $-8.073 * * *$ \\
$\log ($ Leverage) & {$[-0.193]$} & {$[-0.279]$} & {$[-0.178]$} & {$[-3.837]$} \\
& 0.152 & -0.345 & 0.133 & $-0.521^{* *}$ \\
Block holder & {$[0.668]$} & {$[-1.140]$} & {$[0.549]$} & {$[-2.068]$} \\
& & & -0.063 & 0.005 \\
\hline Observations & 4,000 & 4,000 & {$[-1.132]$} & {$[0.054]$} \\
Number of Countries & 31 & 31 & 3,737 & 3,737 \\
Adjusted $\mathrm{R}^{2}$ & 0.919 & 0.703 & 31 & 31 \\
Year dummies & Yes & Yes & 0.917 & 0.703 \\
Bank fixed effects & Yes & Yes & Yes & Yes \\
\hline
\end{tabular}


Figure 1: Time Trends in Board Characteristics - 2000-2008, full sample

This figure shows average board independence and banking experience for all banks in the sample. Board independence is measured as a fraction of board size while banking experience is measured as a fraction of the number of independent directors.

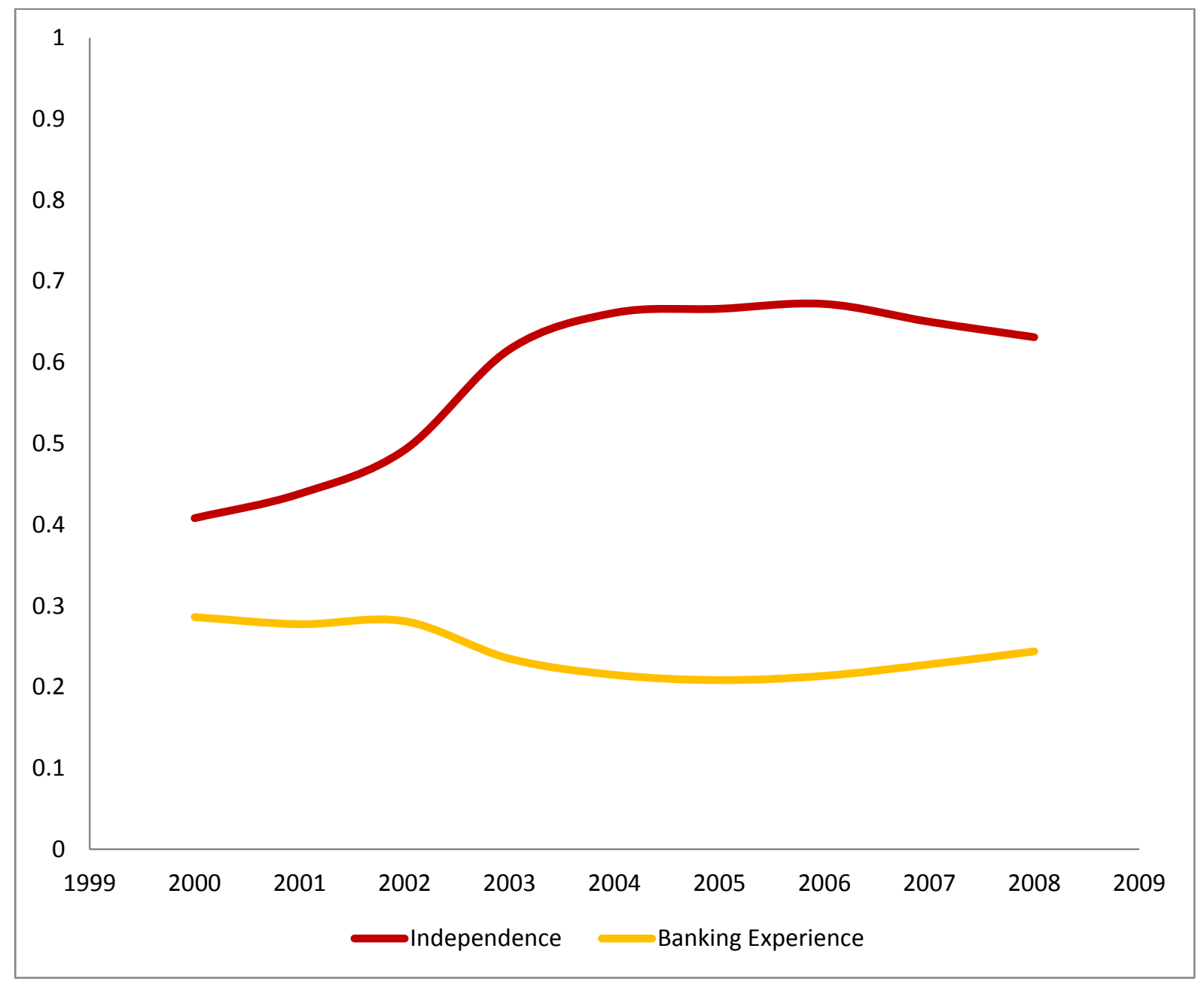


Figure 2: Time Trends in Board Characteristics in Percentages- 2000-2008, full sample

This figure shows average board independence and banking experience for all banks in the sample. Board independence is measured as a fraction of board size while banking experience is measured as a fraction of the number of independent directors. All values are expressed as a percentage of their 2000 levels (year $2000=100)$.

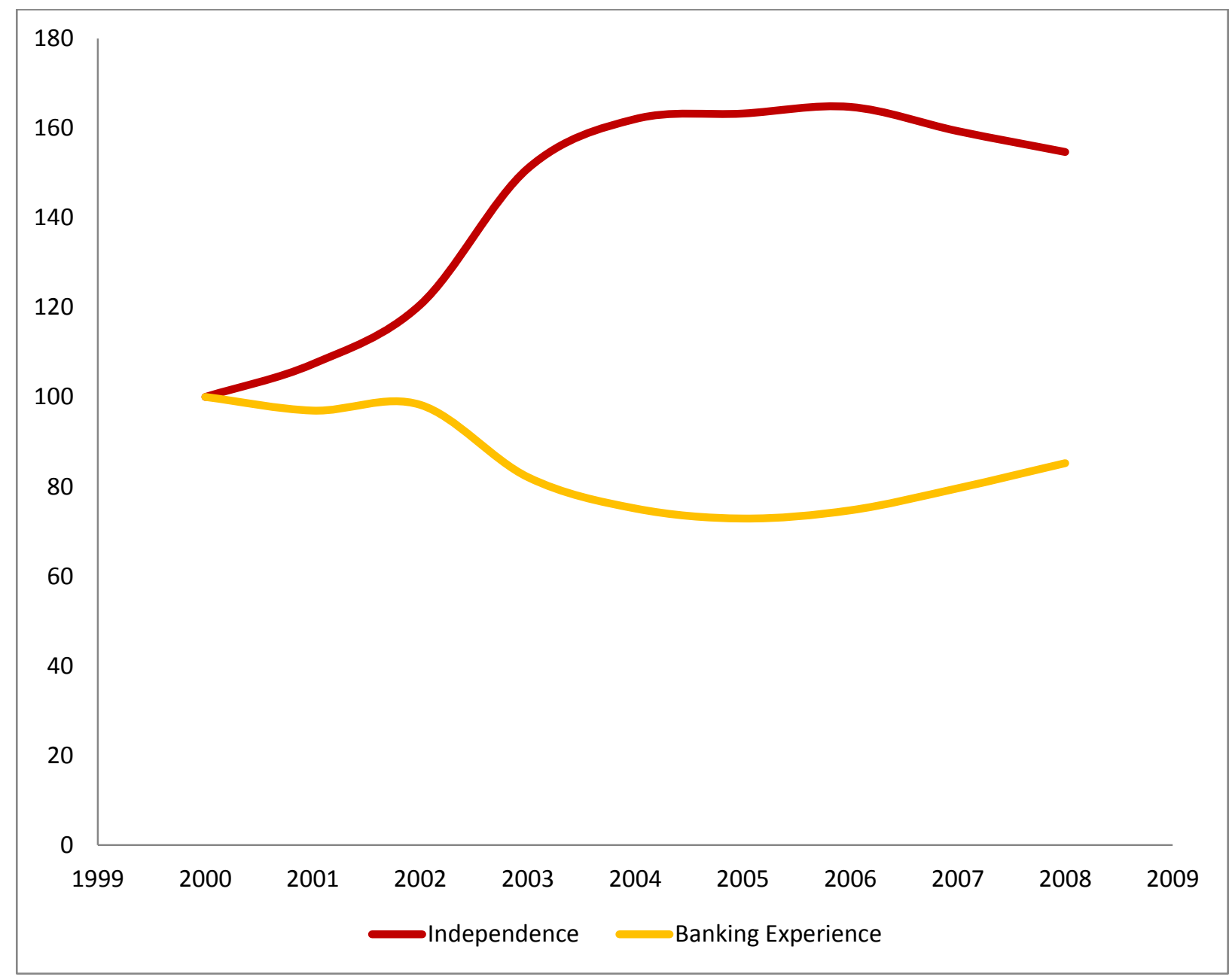


Figure 3: Time Trends in Board Characteristics - 2000-2008, US banks only

This figure shows average board independence and banking experience for all US banks in the sample. Board independence is measured as a fraction of board size while banking experience is measured as a fraction of the number of independent directors. All values are expressed as a percentage of their 2000 levels (year $2000=100)$.

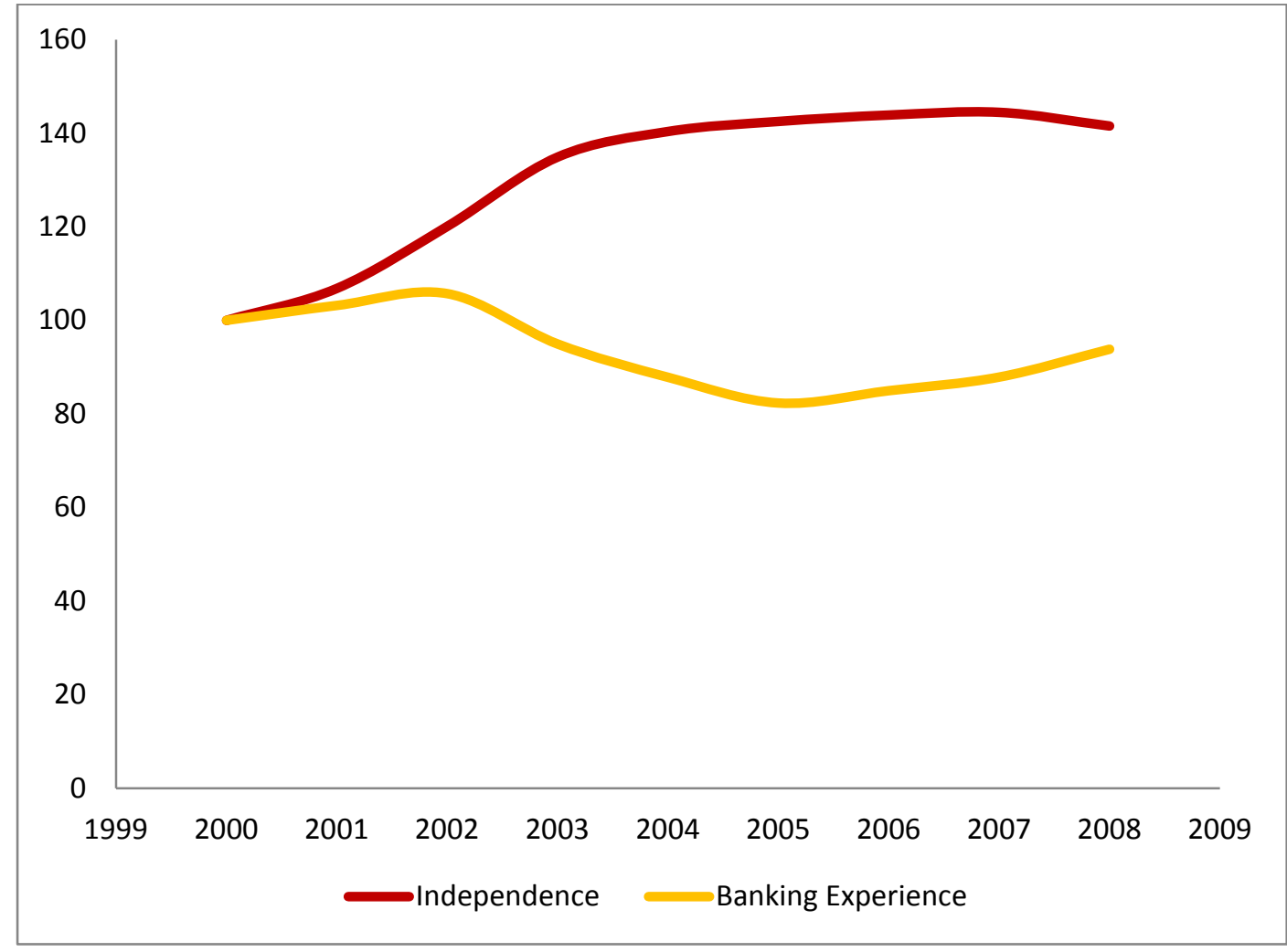


Figure 4: Time Trends in Board Characteristics - 2000-2008, Non-US banks only

This figure shows average board independence and banking experience for all non-US banks in the sample. Board independence is measured as a fraction of board size while banking experience is measured as a fraction of the number of independent directors. All values are expressed as a percentage of their 2000 levels (year $2000=100)$.

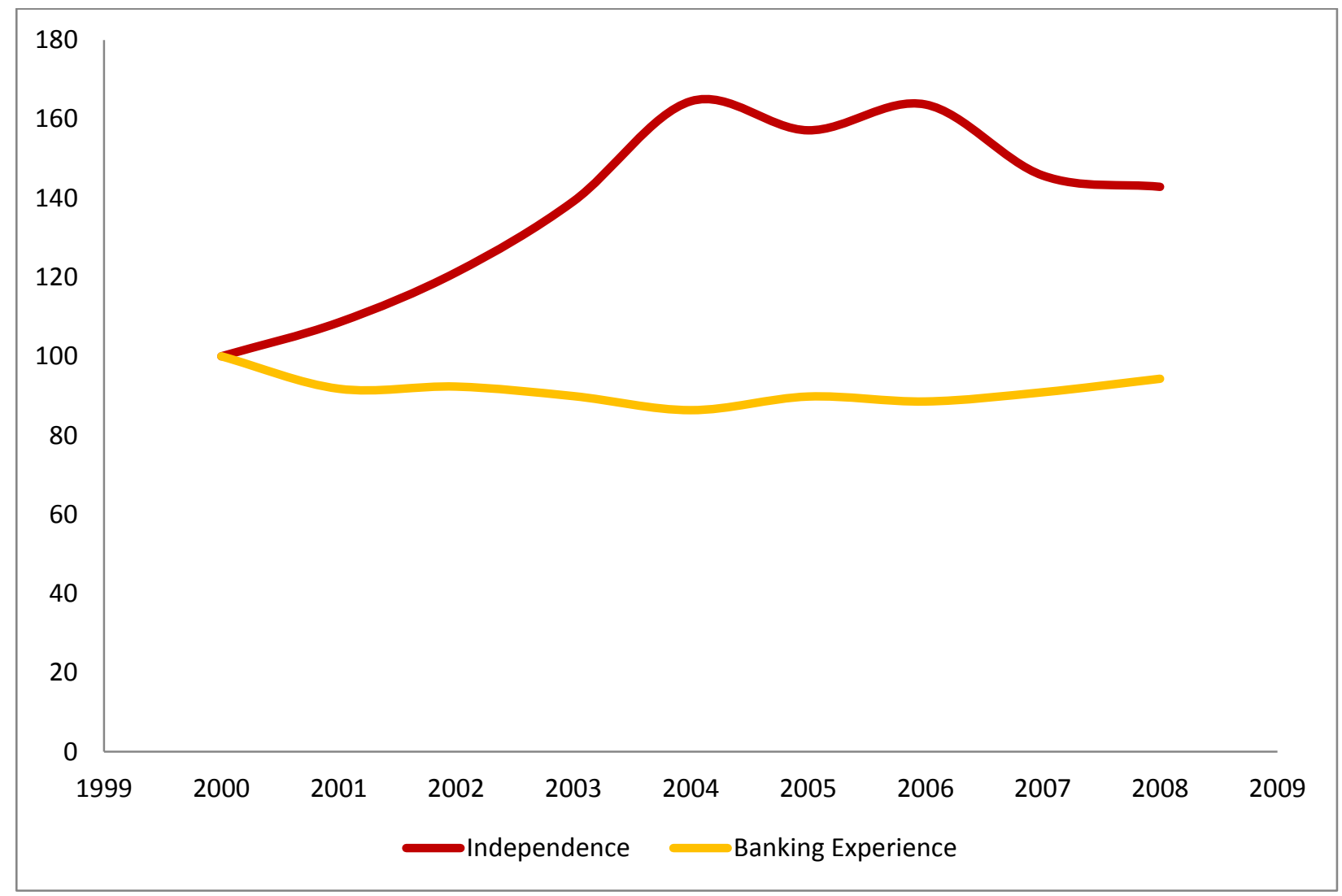

